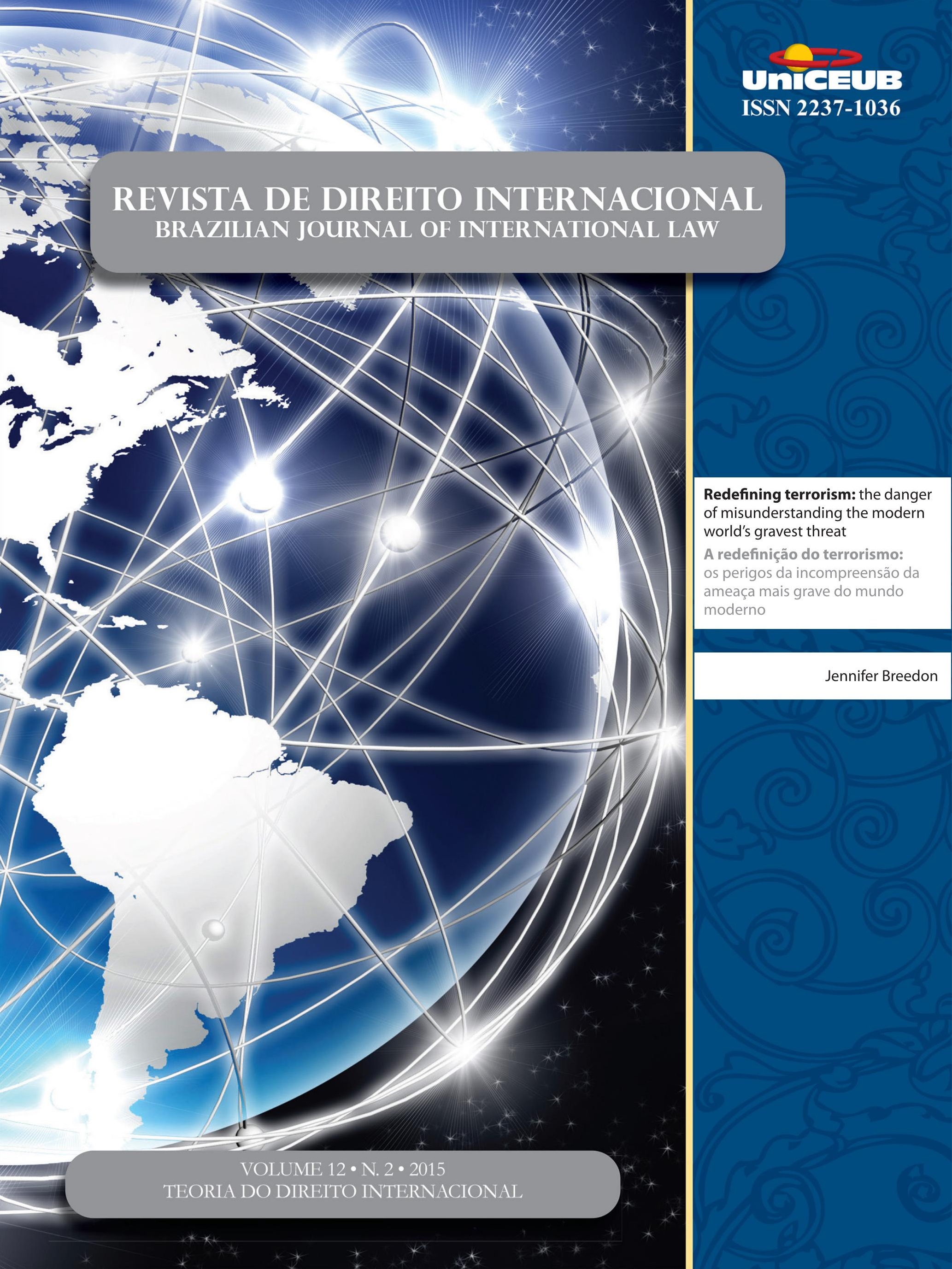




\section{Sumário}

CrôNiCAS DA ATUALIDADE do DiREITo INTERnACIONAL ..................................................... 2 Sarah Dayanna Lacerda Martins Lima, Carina Costa de Oliveira e Erika Braga

CrôniCas do Direito InternaCional dos InVESTIMENTOS ..............................................12 Nitish Monebhurrun

Por que voltar a Kelsen, o jurista do século XX ? 16 Inocêncio Mártires Coelho

O Princípio da Efetividade como conteúdo da norma fundamental (GrundNorm) DE KELSEN

Carlos Alberto Simões de Tomaz e Renata Mantovani de Lima

A JURIDIFICAÇÃo DE CONFLITOS POLÍTICOS NO DIREITO INTERNACIONAL PÚBLICO CONTEMPORÂ-

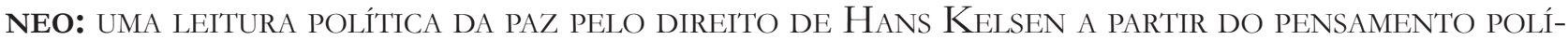
TICO De Claude Lefort

Arthur Roberto Capella Giannattasio

O SINCRETISMO TEÓRICO NA APROPRIAÇÃO DAS TEORIAS MONISTA E DUALISTA E SUA QUESTIONÁVEL UTILIDADE COMO CRITÉRIO PARA A CLASSIFICAÇÃO DO MODELO BRASILEIRO DE INCORPORA-

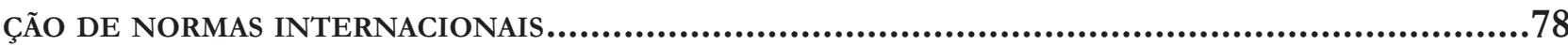
Breno Baía Magalhães

Direito Global em Pedaços: Fragmentação, Regimes e Pluralismo .98 Salem Hikmat Nasser

Por uma TeOria JURÍdica da INTEGRaÇão REgIONAL: A INTER-RELAÇÃO DiREITO INTERNO, DiREITO INTERNACIONAL PÚBLICO E DIREITO DA INTEGRAÇÃO Jamile Bergamaschine Mata Diz e Augusto Jaeger Júnior

A teOria DA INTERCONSTITUCIONALIDADE: UMA ANÁlISE COM BASE NA AMÉRICA LATINA...........160 Daniela Menengoti Ribeiro e Malu Romancini 
O DIÁLOGO HERMENÊUTICO E A PERGUNTA ADEQUADA À APLICAÇÃo DOS TRATADOS INTERNACIONAIS DE DIREITOS HUMANOS NO BRASIL: CAMINHOS PARA O PROCESSO DE INTERNACIONALIZAÇÃO

DA CONSTITUIÇÃO...................................................................................... 176

Rafael Fonseca Ferreira e Celine Barreto Anadon

O DIREITO COMPARADO NO STF: INTERNACIONALIZAÇÃO DA JURISDIÇÃO CONSTITUCIONAL BRASILEIRA

Carlos Bastide Horbach

THE PHILOSOPHY OF INTERNATIONAL LAW IN CONTEMPORARY SCHOLARSHIP: OVERCOMING NE-

GLIGENCE THROUGH THE GLOBAL EXPANSION OF HUMAN RIGHTS

Fabrício Bertini Pasquot Polido, Lucas Costa dos Anjos e Vinícius Machado Calixto

OpORTUNIDADES E DESAFIOS DAS TWAIL NO CONTEXTO LATINO-AMERICANO A PARTIR DE PERSPECTIVAS DOS POVOS INDÍGENAS AO DIREITO INTERNACIONAL

Fernanda Cristina de Oliveira Franco

Por Que uma ANÁlise ECONÔMICA Do DIREITO INTERNACIONAL PÚBLICO? DESAFIOS E PERSPECTIVAS DO MÉTODO NO BRASII

Gustavo Ferreira Ribeiro e Jose Guilherme Moreno Caiado

ANÁliSE ECONÔMICA do DIREITO INTERNACIONAL .263 Michele Alessandra Hastreiter e Luís Alexandre Carta Winter

RACIONALIDADE ECONÔMICA E OS ACORDOS BILATERAIS DE INVESTIMENTO 284 Michele Alessandra Hastreiter e Luís Alexandre Carta Winter

LOOKING FOR A BRICS PERSPECTIVE ON INTERNATIONAL LAW .304 Gabriel Webber Ziero

A INFLUÊNCIA DO DIREITO DESPORTIVO TRANSNACIONAL NO ORDENAMENTO JURÍDICO BRASILEIRO: DA REPRODUÇÃO DE NORMAS À APLICAÇÃO DIRETA PELA JURISDIÇÃO ESTATAL.......................3324 Tiago Silveira de Faria

CONVENCIONALIZAÇÃo DO DIREITO CIVIL: A APLICAÇÃo DOS TRATADOS E CONVENÇÕES INTERNACIONAIS NO ÂMBITO DAS RELAÇÕES PRIVADAS . 
NATIONAL JUdGES AND COURTS AS INSTITUTIONS FOR GLOBAL ECONOMIC GOVERNANCE 356

Juízes e tribunais nacionais como instituições para a governança global 356 Camilla Capucio

Is Trade Governance Changing? 371 Alberto do Amaral Júnior

OS FUNDOS ABUTRES: MEROS PARTICIPANTES DO CENÁRIO INTERNACIONAL OU SUJEITOS PERANTE O DIREITO INTERNACIONAL? 384

Guilherme Berger Schmitt

SHAREHOLDER AGREEMENTS IN PUBLICLY TRADED COMPANIES: A COMPARISON BETWEEN THE

U.S. AND BRAZIL. 402 Helena Masullo

REgulaÇÃo DO INVESTIMENTO ESTRANGEIRO DIRETO NO BRASIL: DA RESISTÊNCIA AOS TRATADOS BILATERAIS DE INVESTIMENTO À EMERGÊNCIA DE UM NOVO MODELO REGULATÓRIO 421 Fabio Morosini e Ely Caetano Xavier Júnior

DA QUALIFICAÇÃo JURÍDiCA dAS Distintas FORMAS DE PRESTAÇão TECNOLÓGICA: BREVE ANÁLISE DO MARCO REGULATÓRIO INTERNACIONAL

Daniel Amin Ferraz

REDEFINING TERRORISM: THE DANGER OF MISUNDERSTANDING THE MODERN WORLD'S GRAVEST THREAT

Jennifer Breedon

As EXECUÇões SELETIVAS E A RESPONSABILIZAÇÃo DE AGENTES TERRORISTAS 485 Alexandre Guerreiro

INTERNATIONAL CRIMINALS AND THEIR VIRTUAL CURRENCIES: THE NEED FOR AN INTERNATIONAL EFFORT IN REGULATING VIRTUAL CURRENCIES AND COMBATING CYBER CRIME Joy Marie Virga

Criminalidad transnacional organizada en el Ámbito del MERCOSUR: ¿Hacia un Derecho Penal Regional?. .528 Nicolás Santiago Cordini e Mariano Javier Hoet 
RUMO À INTERNACIONALIZAÇÃo DA PROTEÇÃO PENAL DO MEIO AMBIENTE: DOS ECOCRIMES AO ECOCÍDIO

Kathia Martin-Chenut, Laurent Neyret e Camila Perruso

Engaging the U.N. Guiding Principles on Business and Human Rights: the inter-AMERICAN COMMISSION ON HUMAN RIGHTS \& THE EXTRACTIVE SECTOR 571 Cindy S. Woods

O DIREITO HUMANO À COMUNICAÇÃo PRÉVIA E PORMENORIZADA DAS ACUSAÇÕES NOS PROCESSOS administrativos: O desprezo do Superior Tribunal de Justiça ao Pacto de San José da Costa Rica e À Corte Interamericana de Direitos Humanos .590

Daniel Wunder Hachem e Eloi Pethechust

A responsabilidade internacional do Brasil em FaCe do CONTRole de ConVENCionaliDADE EM SEDE DE DIREITOS HUMANOS: CONFLITO DE INTERPRETAÇÃO ENTRE A JURISDIÇÃO DA Corte Interamericana de Direitos Humanos e o Supremo Tribunal Federal quanto a LEI DE ANISTIA 612

Carla Ribeiro Volpini Silva e Bruno Wanderley Junior

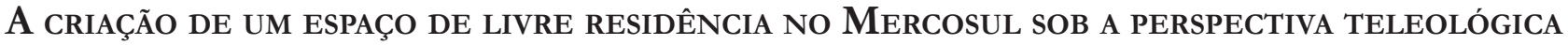
DA INTEGRAÇÃo REGIONAL: ASPECTOS NORMATIVOS E SOCIAIS DOS ACORDOS DE RESIDÊNCIA ....... 631

Aline Beltrame de Moura

A funcionalização como tendênCia evolutiva do Direito Internacional e sua conTRIBUIÇÃO AO REGIME LEGAL DO BANCO DE DADOS DE IDENTIFICAÇÃO DE PERFIL GENÉTICO NO BRASIL

Antonio Henrique Graciano Suxberger

O DIREITO INTERNACIONAL E A PROTEÇÃO DOS DIREITOS DE CRIANÇAS E DE ADOLESCENTES EM CONFLITO COM A LEI EM MOÇAMBIQUE

Bernardo Fernando Sicoche

ObTenÇão de PRovas no EXTERIOR: PARA ALÉM dA LEX FORI E LEX DiLigENTIAE. .685 André De Carvalho Ramos 
A Slight Revenge and a Growing Hope for Mauritius and the Chagossians: The UNClos Arbitral Tribunal's Award of 18 March 2015 on Chagos Marine Protected Area (Mauritius v. United Kingdom)

Géraldine Giraudeau

ANÁLISE DA RESPONSABILIDADE INTERNACIONAL DA UCRÂNIA POR VIOLAÇÃo DOS DIREITOS HUmanos na QUeda do voo da Malaysia Airlines (MH17). .728

Daniela Copetti Cravo

NatureZa JURÍdica do DESENVOLVIMENTO SUSTENTÁVEL No DIREITO INTERNACIONAL ........739 Pedro Ivo Diniz

A INFLUÊNCIA Da SOFT LAW NA FORMaÇão do DiREITo AMBIENTAL .767 Leonardo da Rocha de Souza e Margareth Anne Leister

As COMPLICADAS INTER-RELAÇÕES ENTRE OS SISTEMAS INTERNOS E INTERNACIONAIS DE PROTEÇãO DO DIREITO AO MEIO AMBIENTE SADIO. 785 José Adércio Leite Sampaio e Beatriz Souza Costa 


\title{
Redefining terrorism: the danger of misunderstanding the modern world's gravest threat*
}

\author{
A redefinição do terrorismo: os perigos da \\ incompreensão da ameaça mais grave do \\ mundo moderno
}

\section{Jennifer Breedon**}

"The Security Council of the United Nations calls upon all Member States to ... [c] ooperate, particularly through bilateral and multilateral arrangements and agreements, to prevent and suppress terrorist attacks and take action against perpetrators of such acts ... [understanding] the need to enhance coordination of efforts on national, subregional, regional and international levels in order to strengthen a global response to this serious challenge and threat to international security."

"The [adopted legal concept of 'terrorism'] is imprecise; it is ambiguous; and above all it [currently] serves no operative legal purpose." Richard Baxter

\section{Abstract}

The international community has been, and remains, unable to prevent episodes of mass murder resulting for modern-day terrorist ideologies due to three basic failures: (1) the failure to face the problem squarely and understand its real nature, (2) the failure to recognize that it is possible to prevent mass murder of individuals, and (3) the failure to act once knowledge of the violent intent of perpetrators is recognized. This paper will face these challenges by uncovering the fundamental issues underlying the failure of the international community to adopt a uniform and transnational definition of modern-day terrorism boldly and honestly. Terrorism must be codified in a manner that is consistent with its modern forms and acceptable to the global community's regional definitions and differences by highlighting the similarity and allowing for extraterritorial prosecution to prevent such acts in an ad hoc tribunal. This paper will address the following issues: (1) It will highlight the need for universal codification of modern terrorism in order to prevent and prosecute modern terrorists by analyzing current forms of international law regarding terrorism; (2) Then, it will identify the objective intentions of modern extremist organizations by highlighting several ongoing threats and how such threats relate to international legal principles; and (3) finally, after highlighting the gaps in the current legal system involving modern terrorism, it will use the existing conventions on "terrorism" to posit a universal definition that should be agreeable to all UN Member States in efforts to combat the spread of violent extremism. If the world continues to fear political "incorrectness" it will never understand the motives of mo- 
dern extremist groups today. Most modern "terrorist" organizations operate with the same genocidal intent seem throughout history when certain groups sought to annihilate or eliminate entire groups of human beings. If the global community fails to reach a consensus on a uniform codification of terrorism under international law, it will remain nearly impossible to prevent a massive loss of human life. To provide justification for its premise, this article will take a brief look at five of the most prevalent modern "terrorist" organizations that pose the gravest threat to humanity in our time.

Keywords: Terrorism. Transnational law. Rule of law. Genocide.

\section{Resumo}

A comunidade internacional tem sido, e continua a ser, incapaz de evitar episódios de mortes em massa resultante e modernas ideologias terroristas, devido a três falhas básicas: (1) não-enfrentamento do problema de forma direta e de compreensão da sua verdadeira natureza, (2) a falha em reconhecer que é possível para evitar o assassinato em massa de indivíduos, e (3) a omissão, uma vez conhecida as intenções violentas dos agressores. Este trabalho enfrentará esses desafios, descobrindo as questões fundamentais subjacentes ao fracasso da comunidade internacional em adotar uma definição uniforme e transnacional contra o terrorismo, com coragem e honestidade. Este artigo irá abordar as seguintes questões: (1) Seá destacado a necessidade de codificação universal do terrorismo moderno, a fim de prevenir e reprimir atos contemporâneos, analisando as formas atuais do direito internacional sobre o terrorismo; (2) Em seguida, identifica-se as intenções objetivas de organizações extremistas modernas, destacando várias ameaças e como tais ameaças dizem respeito a princípios legais internacionais; e (3) finalmente, depois de destacar as lacunas do actual sistema jurídico envolvendo terrorismo moderno, usa-se as convenções existentes sobre o "terrorismo" para postular uma definição universal que deve ser aceitável por todos os Estados Membros das Nações Unidas. Se o mundo continua a temer "incorreção" político que ela nunca vai entender os motivos de grupos extremistas modernos hoje. Se a comunidade global não conseguir chegar a um consenso sobre uma codificação uniforme do terrorismo, continuará a ser quase impossível evitar uma enorme perda de vidas humanas. Para justificar a sua premissa, este artigo realiza uma breve análise das organizações que mais se destacam atualmente.

Palavras chaves: Terrorismo. Direito transnacional. Estado de Direito. Genocídio.

\section{INTRODUCTION}

Governments and media entities label many forms of violence as "terrorism." The negative connotation this term carries with it does little to resolve the fundamental threat of this modern form of mass violence. All that a "terrorism" label does is perpetuate fear while offering no real understanding of the underpinnings of this treat. Governments and militaries remain paralyzed against this global threat of "terrorism"- a term that still has no universal definition. ${ }^{2}$ The faces of violence and war have changed drastically as threats of terror continue, but the international community has failed to reexamine unconventional warfare in order to understand the extent of the terrorist threat. Therefore, non-state actors - such as violent extremist organizations - are able to act with impunity, just as genocidal State Officials leaders did prior to World War Two and the codification of international crimes at the Nuremburg Tribunals. ${ }^{3}$ On the most basic level, the current definitions of terrorism generally possess the following elements: (1) violence or the threat of violence, (2) stealth conflict, (3) political motivation, (4) intent to frighten, and the (5) targeting of civilians. ${ }^{4}$ These ele-

2 When widespread acts of systematic violence are carried out by non-state actors, the default label attached to such acts is "terrorism" yet the international community has yet to solidify any uniform definition outlining the criminal elements of the act so that it can be prosecuted on an international level. Regional organizations and state governments have delineated acceptable definitions of "terrorism" in their respective territories, since most times, "terrorism" is whatever a government or "legitimate" authority wants it to be: from secessionism to political graffiti. Cite

3 Mary Ellen O'Connell, Richard F. Scott \& Naomi Rott-Ariaza, The International Legal System 509 (Robert C. Clark et al. eds., 6th ed. 2010). Despite the various conventions that address forms of "terrorist acts," none have yet been able to thwart the cancerous growth that organized group violence poses today. David Luban, Julie R. O'Sullivan \& David P. Stewart, International and Transnational Criminal Law 677 (Vicki Been et al. eds., Aspen Publishers 2010). The existing treaties relating to terrorism fall short of establishing a universal system to prevent the atrocities that are continuing to occur at the hands of certain terrorist organizations.

4 Luban, supra note 5, at 670-71 (emphasis added). 
ments are simply inaccurate and incomplete. What is needed is factual codification that takes an honest look at the goals and motivation of modern extremist organizations in order to prosecute and prevent the main perpetrators. ${ }^{5}$ While the current laws governing terrorism were drafted in the 1960s and 1970s when sporadic "acts of violence" were carried out for political purposes, extremist organizations today pose greater threats of mass violence through unconventional warfare and the proliferation of nuclear weapons necessitating a realistic transnational look into the goals and motivations of such organizations. ${ }^{6}$

This paper will identify the objective intentions of modern extremist groups (that governments label "terrorists") by highlighting how modern "terrorist acts" fall under codified and universal international criminal laws, rendering a new title or uniform definition unnecessary. In his book entitled Worse Than War, Daniel Goldhagen discusses the duty that individuals, institutions, and governments have to preserve humanity against repeated campaigns where groups or governments have sought to eliminate entire people groups through mass murder or forced displacement (which this paper will refer to as "eliminationist campaigns"). ${ }^{7}$ He states that the international community has been unable to prevent episodes of mass murder because it fails to understand the real nature of eliminationist campaigns, and then once the violent intent of the mass murderers is understood, they have failed to act in order to prevent. ${ }^{8}$ Government definitions of "terrorism" purposely fail to account for the true intentions of these violent groups.

5 Daniel Jonah Goldhagen, Worse Than War: Genocide, Eliminationism, and the Ongoing Assault on Humanity 550 (Public Affairs Publisher, 1st ed. 2009) (discussing the importance of preventative measures to combat campaigns bent on the annihilation and elimination of nations, religions, or groups).

6 Reuven Young, Defining Terrorism: The Evolution of Terrorism as a Legal Concept in International Law and its influence on Definitions in Domestic Litigation, 29 B. C. Int'l \& Comp. L. Rev. 23, 28-29 (2006). See Luban, supra note 5, at 680 (quoting David Luban, The Way on Terrorism and the End of Human Rights, 22 Phil. \& Pub. Poly. Q. 9 (2002) (stating that "Given the unique and heightened danger that suicide terrorists pose, a stronger response that grant potential terrorists fewer rights may be justified."); See also Goldhagen, supra note 6, at 512. In 2006, criminal law professor, Thomas Weigend, noted that the types of terrorism which transcend national boundaries are easier to combat through international cooperation which can only be achieved by first agreeing upon a universal definition of terrorism. Thomas Weigend, The Universal Terrorist, $912 \mathrm{~J}$. Int. Crim. Justice 4(5), 1 (Nov. 1, 2006).

7 Goldhagen, supra note 6, at xi.

8 Goldhagen, supra note 6, at xi.
If the current network of sovereign states comprising the international legal system continues to fear political "incorrectness" or place proper criminal labels on the violence, it will never be able to prevent future occurrences of eliminationism or protect the innocent lives that we know are already targets. ${ }^{9}$

\section{Current Laws on “Terrorism.”}

The first time the global community attempted a uniform definition of terrorism was in 1937 through the adoption of a convention at the League of Nations. ${ }^{10}$ Since 1963, the international community has elaborated fourteen universal legal instruments attempting to prevent terrorist acts. ${ }^{11}$ In 1972, the Sixth Legal Committee of the United Nations (UN) General Assembly attempted a universal definition of terrorism but, once again, failed to reach a consensus. ${ }^{12}$ Finally, in lieu of a universal, over-arching definition of terrorism, the UN passed numerous conventions to address types of violent acts of terror involving civil aviation, the taking of hostages, certain types of bombing, and the transnational organized financing of terror acts. ${ }^{13}$ The UN Security Council

9 Bruce Hoffman, Inside Terrorism, in Global Affairs 192, 205 (Columbia University Press) (Michelle Baird et al. eds., 3d ed. Thomson Wadsworth 2007).

10 League of Nations Convention on the Prevent and Punishment of Terrorism, Council on Foreign Rel., http://www.cfr.org/ terrorism-and-the-law/league-nations-convention-prevention-punishment-terrorism/p24778 (last visited Feb. 11, 2015). O'Connell, supra note Erreur : source de la référence non trouvée, at 59-61. (That convention never came into force because two years later, the second World War was launched resulting in the replacement of the League of Nations with the United Nations in 1945. See History: From the League of Nations to the United Nations, UN Office at Geneva, http://www.unog.ch/80256EDD006AC19C/\%28httpPag es\%29/242056AEA671DEF780256EF30037A2A8?OpenDocume nt (last visited Feb. 11, 2015).

11 See Luban, supra note 5, at 669-70 (stating that one study counted 109 different definitions of terrorism between 1936 and 1981 even noting how the UN, itself, has differing definitions, which is likely because Security Council resolutions are subject to vetostate approval and are binding as international law while General Assembly resolutions are easier to pass and not considered binding on their face); See also The United Nations Global CounterTerrorism Strategy, G.A. Res 60/288, U.N. Doc. A/RES/60/288 (Sept. 20, 2006).

12 Bruce Hoffman, Inside Terrorism, in Global Affairs 192, 205 (Columbia University Press) (Michelle Baird et al. eds., 3d ed. Thomson Wadsworth 2007).

13 Convention on Offences and Certain Other Acts Committed on Board Aircraft, signed at Tokyo on 14 September 1963. (Deposited with the Secretary-General of the International Civil 
has also addressed the issue of terrorism delineation and prevention by declaring that UN Member States are individually obligated to prevent violence resulting from "terrorist" activities. ${ }^{14}$ It noted a close connection between international terrorism and transnational organized crime which this paper agrees should be amended into the Transnational Organized Crime Convention. ${ }^{15}$

The conflicting definitions of "terrorism" amongst regional actors displays the gaps in opinion of terrorism, but also shows how the universally undefined principle is used as political rhetoric to downgrade any violence with which the government cannot prosecute or prevent. For example, the European Union (EU) defines terrorism as, "criminal acts carried out by non-state or state actors, individuals, or groups that use some form of violence irrespective of the result, committed with the intention to intimidate a civilian population, or compel a government, military, or other formal institution in doing or abstaining from doing something, or another purpose." ${ }^{\text {"T }}$ The Organization of Islamic

Aviation Organization), available at https://treaties.un.org/Pages/ DB.aspx?path=DB/studies/page2_en.xml; Conventions on Terrorism Involving Civil Aviation (passed in 1963, Convention for the Suppression of Unlawful Seizure of Aircraft of 1970, 1971, Terrorism involving Civil Aviation of 2010; 1979 International Convention against the Taking of Hostages; 1997 International Convention for the Suppression of Terrorist Bombings; International Convention for the Suppression of the Financing of Terrorism 1999, International Convention for the Suppression of Acts of Nuclear Terrorism 2005.

14 S. C. Res. 1373 (2001), S/Res/1373 (Sept. 28, 2001) Adopted by the Security Council at its 4385th meeting, on 28 September 2001.

15 S. C. Res. 1373 (2001), S/Res/1373 (Sept. 28, 2001) Adopted by the Security Council at its 4385th meeting, on 28 September 2001. at 4; See also Transnational Organized Crime Convention art. 3 (2) (a)(d), Nov. 15, 2000, 40 I.L.M. 335 (2001); G.A. Res. 55/383 at 25, art. 3 (2000); U.N. Doc. A/RES/55/25 at 4, art. 3 (2001) "an offence is transnational in nature if: (a) it is committed in more than one state; (b) it is committed in one state but a substantial part of its preparation, planning, direction or control takes place in another state; (c) it is committed in one state but involves an organized criminal group that engages in criminal activities in more than one state; or (d) it is committed in one state but has substantial effects in another state., art. 6 (a)(i) criminal offences, when committed intentionally [under this convention, include] the conversion or transfer of property, knowing that such property is the proceeds of crime, for the purpose of concealing or disguising the illicit origin of the property or of helping any person who is involved in the commission of the predicate offence to evade the legal consequences of his or her action." 6 (b)(i) "the acquisition possession or use of property, knowing, at the time of receipt, that such property is the proceeds of crime." Art. 23(b) the use of physical force, threats or intimidation to interfere with the exercise of official duties by a justice or law enforcement official.

16 The Nature of Terrorism: Defining terrorism within the EU
Cooperation (OIC) defines terrorism as the following:

[A]ny act of violence or threat thereof notwithstanding its motives or intentions perpetrated to carry out an individual or collective criminal plan with the aim of terrorizing people or threatening to harm them or imperiling their lives, honor, freedoms, security or rights or exposing the environment or any facility or public or private property to hazards or occupying or seizing them, or endangering a national resource, or international facilities, or threatening the stability, territorial integrity, political unity or sovereignty of independent States. ${ }^{17}$

The Association of Southeast Asian Nations (ASEAN) drafted its own convention on "counter terrorism" but failed to specifically define "terrorism." 18 It merely referred to "terrorism" as understood through various international conventions and used rhetoric that obligated its own member states to cooperate with each other in order to prevent instances of "terrorist acts." It proposed an extradition cooperation treaty and continues to mandate that its signatories identify the root causes of terrorism to form effective countermeasures. ${ }^{19}$ Another interesting approach is the Russian

16 (June 28, 2007), available at http://www.transnationalterrorism. eu/tekst/publications/European\%20Definitions.pdf. For an excellent overview on the current attempts to define terrorism and a global context of each specific definition, see Young, supra note 6. The EU's final "Framework Decision," adopted by the EU Member States in 2002, "offer[ed] a firm foundation for an internationally accepted definition of terrorism encompassing elements of other international conventions and keeping it broad enough to 'reflect the normative consensus that terrorism undermines the State and the political process, The Nature of Terrorism: Defining terrorism within the EU, at 11 .

17 Organization of the Islamic Conference (OIC), Convention of the Organisation of the Islamic Conference on Combating International Terrorism, art. 1 (2), July 1, 1999, Annex to Resolution No: 59/26-P, available at http://www.refworld.org/docid/3de5e6646.html (last visited Feb. 11, 2015). This convention was adopted at the Organization of the Islamic Conference's twenty-sixth session of the Islamic conference of foreign ministers in Ouagadougou, Burkina Faso, in July 1999.

18 ASEAN Convention on Counter-Terrorism, Jan. 13, 2007, in Documents on Combatting Transnational Crime and Terrorism: A Compilation of ASEAN Declarations, Joint Declarations, and Statements on Combatting Transnational Crime and Terrorism 61, 61-68 (ASEAN Secretariat Public Outreach and Civil Society Division, Copyright Association of Southeastern Asian Nations, 2012), available at http://www.asean.org/resources/publications/ asean-publications/item/asean-documents-on-combating-transnational-crime-and-terrorism (Follow link "ASEAN Documents on Combating Transnational Crime and Terrorism" and then click on "Download" to pdf).

19 Id. preamble (discussing the "grave danger posed by terrorism to innocent lives, infrastructure and the environment, regional and international peace and stability as well as to economic develop- 
Federation's laws regarding counter-terrorism, as it reaches beyond the borders of Russia if the government believes that "terrorist" activities are affecting Russia or the Russian political system. ${ }^{20}$ The International Tribunal for Rwanda (ICTR) discussed terrorism in its founding statute giving it the power to prosecute the following offenses:

[C]ommitting or ordering to be committed serious violations of Article 3 common to the Geneva Conventions of 12 August 1949 for the Protection of War Victims, and of Additional Protocol II thereto of 8 June 1977. These violations shall include, but shall not be limited to: a) Violence to life, health and physical or mental well-being of persons, in particular murder as well as cruel treatment such as torture, mutilation or any form of corporal punishment; b) Collective punishments; c) Taking of hostages; d) Acts of terrorism; e) Outrages upon personal dignity, in particular humiliating and degrading treatment, rape, enforced prostitution and any form of indecent assault; f) Pillage; g) The passing of sentences and the carrying out of executions without previous judgement pronounced by a regularly constituted court, affording all the judicial guarantees which are recognised as indispensable by civilised peoples; $\mathrm{h}$ ) Threats to commit any of the foregoing acts. ${ }^{21}$

Similarly, the International Criminal Tribunal for the Former Yugoslavia (ICTY) attempted to discuss and define the crime of terror in the Stanislav Galic case stating that

[e]lements of the Crime of Terror include: (1) Acts of violence directed against the civilian population or individual civilians not taking direct part in hostilities causing death or serious injury to body or health within the civilian population; (2) The

ment"). "Subject to the consent of the Parties concerned, Parties shall cooperate to address the root causes of terrorism and conditions conducive to the spread of terrorism to prevent the perpetration of terrorist acts and the propagation of terrorist cells." Id. art. VI (2) (emphasis added).

20 See Federal Law No. 35-FZ of 6 March 2006 on Counteraction Against Terrorism, Adopted by the State Duma on Feb. 26, 2006, Endorsed by the Federation Council on March 1, 2006, available at http://www.coe.int/t/dlapil/codexter/Source/country_profiles/ legislation/CT\%20legislation $\% 20-\% 20$ Russian $\% 20$ Federation.pdf. In Russia, terrorism is defined as the "practices of influencing the decisions of government, local self-government or international organizations by terrorizing the population or through other forms of illegal violent action . . . [using any] ideology of violence. Id., at art. 3. The definition of terrorist activity is even broader and includes the following acts: propaganda of terrorist ideas, dissemination of materials or information which call to terrorist activity, justify or support the need for such activity, and also "informational or other types of aiding and abetting with regard to planning, preparation or implementation of a terrorist act." Id.

21 S.C. Res. 955, art. 4, U.N. Doc. S/Res/955 (Nov. 8, 1994); 33 I.L.M. 1598 (1994). offender willfully made the civilian population or individual civilians not taking direct part in hostilities the object of those acts of violence; (3) The above offence was committed with the primary purpose of spreading terror among the civilian population. ${ }^{22}$

Acts of terrorism can be currently prosecuted by the international criminal tribunals for the former Yugoslavia (ICTY) and Rwanda (ICTR) only if they amount to crimes against humanity and/ or war crimes (see Arts. 2, 3, and 5 of the ICTY Statute and Arts. 3 and 4 of the ICTR Statute). The only exception is the Special Tribunal for Lebanon (STL), which has jurisdiction over terrorist acts (see Art. 2(a) of the STL Statute). However, the Special Tribunal acts under Lebanese domestic law and not international law. The International Criminal Court (ICC) does not have jurisdiction over terrorism as a distinct crime. Terrorism is also excluded from the list of war crimes provided in Article 8 of the Rome Statute of the International Criminal Court. The only manner in which the International Criminal Court could exercise jurisdiction over acts of terrorism is if terrorist acts would amount to another crime over which the Court has jurisdiction (for instance, crimes against humanity under Article 7 of the Rome Statute). ${ }^{23}$

Although these definitions contain basic similarities, they fail to account for any religious inspiration, and therefore, are unable to delineate the actual intention (or mens rea) of modern day extremist organizations since they do not consider religious or eschatological aspirations as goals of said organizations. This paper argues that modern violent extremist groups intend to commit international crimes (such as genocide, conspiracy to commit genocide, and crimes against humanity) that are already universally defined, thus rendering the necessity to determine a universal definition of "terrorism" legally moot. ${ }^{24}$

Legal scholars that have proposed definitions based on the regional elements of "terrorism" understand this crucial gap and have attempted to propose general guidelines

22 Prosecutor v. Galic, Case No. IT-98-29-T, Judgment, \ 4 (Int'l Crim. Trib. for the Former Yugoslavia Dec. 5, 2008). "The Prosecution is required to prove not only that the Accused accepted the likelihood that terror would result from the illegal acts . but that that was the result which he specifically intended [as] [t] he crime of terror is a specific-intent crime." Id.

23 Terrorism, Int'l Crimes Database, http://www.internationalcrimesdatabase.org/Crimes/Terrorism (last visited Feb. 1, 2015); Rome Statute of the International Criminal Court, supra note Erreur : source de la référence non trouvée.

24 (Dan) The BBC has stopped using the term terrorism and gone with the idea that a bombing is a bombing, a shooting is a shooting, and "terrorism" is a term used by states to inspire fear. 
for future attempts to universally codify terrorism. ${ }^{25}$ Two examples are Ben Saul, a law and policy scholar, and Susan Tiefenbrun. Saul proposed the following definition: (1) Any serious, violent, criminal act intended to cause death or serious bodily injury, or to endanger life including by acts against property; (2) committed outside an armed conflict; (3) for a political, ideological, religious or ethnic purpose; and (4) intended to: (a) create extreme fear; and (b) seriously intimidate a population; or (c) unduly compel a government or an international organization to do or to abstain from doing any act. Saul notes in his proposal that "advocacy, protest, dissent or industrial action which is not intended to cause death, serious bodily harm or serious risk to public health or safety does not constitute a terrorist act."26 This would preclude future "terrorist labels" to populations exercising their inherent right to self-determination. Along similar lines, Tiefenbrun proposed five abstract elements of terrorism: (1) The perpetration of any violence; (2) targeting of innocent civilians; (3) intent to cause violence; (4) for the purpose of causing fear, coercing or intimidating an enemy; (5) "in order to achieve some political, military, ethnic, ideological, or religious goal". ${ }^{27}$

There is a discernable distinction between organized violent extremism and rebellion movement contained within a population for purely self-determination purposes within that delineated territory. ${ }^{28}$ Global powers have historically championed violence in pursuit of political aims (or violence for the cause of "self-determination") since the age of colonialization and imperialism came to an end. ${ }^{29}$ In 1949, the revised codification of the Geneva Conventions highlighted the changing face of political opposition and violence today. "Wars known as 'wars of national liberation' form a general exception to violence with domestic political aims that many label as "terrorist acts." 31 However, "even when

25 O'Connell, supra note 4, at 60.

26 The Nature of Terrorism: Defining terrorism within the EU, supra note 53, at 14 (emphasis added).

27 The Nature of Terrorism: Defining terrorism within the EU, supra note 53, at 14 (emphasis added). at 15 (emphasis added).

28 See Bruce Hoffman, Inside Terrorism, in Global Affairs, supra note Erreur : source de la référence non trouvée, at 206-09 (discussing the inevitable trajectory of terrorism if it remains undefined).

29 Bruce Hoffman, Inside Terrorism, in Global Affairs, supra note Erreur : source de la référence non trouvée, at 205-217.

301987 Additional protocol Geneva convention (pg 1323-1324)) Geneva Convention, http://www.icrc.org/eng/war-and-law/treaties-customary-law/geneva-conventions/

31 For a thorough and compelling report on the various faces of intra-national or domestic terrorism see The Nature of Terrorism: Defining terrorism within the EU, supra note 37. UN Charter art. the use of force is legally and morally justified, the right of self-determination has its limits." ${ }^{32}$

The philosophical intentions of modern extremists mirror the language of eliminationist campaigns that led to prior instances of genocide. ${ }^{33}$ Transnational terrorism naturalizes national boundaries and involves groups whose intent is to operate beyond national boundaries through the use of violence. ${ }^{34}$ Violent Extremists

1, para. 2; On the basis of this principle, the $\mathrm{UN}$ has been induced to adopt a supportive position towards peoples fighting in the exercise of their right of self-determination. This point of view, which has repeatedly been confirmed in resolutions and declarations, is now universally recognized. This would allow proper prosecution of people who commit a crime through the use of political violence since violent uprising is inspired by the view that political freedoms are somehow restriction by the incumbent government in a sovereign state. It is important to keep in mind that one of the main contentions preventing the international community from accepting a universal definition is the, now commonplace, quip that "one man's terrorist is another man's 'freedom fighter," originally coined in Gerald Seymour, Harry's Game (1975). Once such example of this displaced and politically motivated labeling is the situation in the eastern parts of Ukraine as rebel groups seek to separate from the rule of the Western-influenced Kiev government and live under Russian custom, laws, and leadership. See Anthony Deutsch \& Gabriela Baczynska, Malaysia: Dutch Report Suggest MH-17 shot down from ground, Reuters (Sept. 9, 2014, 1:41 PM), http://www. reuters.com/article/2014/09/09/us-ukraine-crisis-mh17-investigation-idUSKBN0H40LM20140909. MH17 Verdict: Real Evidence Points to US-Kiev Cover-up of Failed "False Flag", Twenty-First Century Wire \& Global Res. (July 17, 2014), http://www.globalresearch.ca/mh17-verdict-real-evidence-points-to-us-kiev-coverup-of-failed-false-flag/5393317; see also Tyler Durden, Ukraine Releases YouTube Clip "Proving" Rebels Shot Down Malaysian Flight MH-17, zerohedge.com (July 17, 2014, 7:46 PM), http:// www.zerohedge.com/news/2014-07-17/ukraine-releases-youtubeclip-proving-rebels-shot-down-malaysian-flight-mh-17.

$32 I d$. at 205. The UN's "encouragement for wars of national liberation and the right of self-determination" renders any attempt to prosecute episode of systematic violence moot as it counteracts the UN's purpose in promoting self-determination. See Hoffman, Inside Terrorism, in Global Affairs, supra note Erreur : source de la référence non trouvée, at 212-17. The broad generalizations of acts that have been associated with the current-accepted definitions of terrorism (as fear for political change) have caused any resolution that aims to prevent such violence impracticable to incorporate on a domestic level, as state governments would be incapable of integrating legislation to prosecute liberation movements who intend secessionist strategies. Id.

33 The term "transnational" means "violating another nation's territorial sovereignty or operating in or involving more than one country; extending or going beyond national boundaries." See "Transnational" Definition, Merriam-Webster Dictionary, http:// www.merriam-webster.com/dictionary/transnational, (last visited Feb. 11, 2015) (stating that "transnational" means "operating in or involving more than one country").

34 Ex (Naturalizes national boundaries. We also champion the SPLA, who operated from Ethiopia and Kenya with the intent of using violence in Sudan to overthrow the government. ) Understanding that modern extremist organizations seek to recast and refashion their world 
today that follow certain eschatological ideologies intend solely "to bring about global dominance and international governance through the use of violence and mass extermination aimed at civilians who do not abide by their ideas of religious rule". ${ }^{35}$ Therefore, the current definitions and conventions of "terrorism" are no longer applicable to acts that the modern world considers "terrorism." Organizations such as the Islamic State of Iraq and the Levant (more commonly known as ISIS) ultimately seek to bring about political domination through the creation of a global Islamic Government (or "Caliphate") as evidenced in the 2014 speech of its self-proclaimed Caliph (leader), Abu Bakr al Baghdadi. ${ }^{36}$

under their own versions of "international justice" often resulting in the creation a new global empire, is an important concept to understand in codifying a modern definition of this form of terrorism. Goldhagen, supra note Erreur: source de la référence non trouvée, at 492 (noting that certain forms of Political Islam have elements that exacerbate eliminationist tactics such as the religious consecration of Allah's goals to which slavish devotion is due, the reflexive and insistence public demonization of its opponents, and a culture of death that glorifies those who die or kill others in the name of Allah's law). For a great explanation about the vast majorities of Muslim populations that fear such extremism, see Yasmine Hafiz, Muslims worldwide fear the rise of Islamic Extremism, Huffington Post (updated July 23, 2014 11:59 AM), http://www. huffingtonpost.com/2014/07/02/muslims-against-extremism-pewsurvey_n_5551693.html.

35 The intent of violent Eliminationist campaigns is often documented or promulgated in their publicized statements or charters See e.g. Adolf Hitler, Mien Kampf (1927); see also e.g. Hamas Leader Khaled Mash'al at a Damascus Mosque: “The Nation of Islam Will Sit at the Throne of the World and the West will be full of remorse when it's too late": No. 1087, MEMRI Special Dispatch Series (Feb. 7, 2006), www.memri.org/bin/articles.cgi?Area $=$ sd\&ID=SP1 08706\&Page $=$ archivesMarija Ristic, ICJ rejects Genocide Claims of Serbia and Croatia, supra note 29 (displaying that although the ICJ found that the act of genocide had been established, the intentional element of genocide was lacking. Here, the Genocide Convention's element that a perpetrator possess an "intent to destroy, in whole or in part, a national, ethnical, racial or religious group as such" is essential to such a finding and is considered "dolus specialis," meaning specific intent, id.); Recently, the International Court of Justice concluded that genocide could not occur in a court of lawif the mental element (mens rea or intent) of genocide elements was not met-despite an overt act of genocide and thousands of deaths.

36 See Amir Abdallah, URGENT Video: ISIS releases Abu Baker al-Baghdadi sermon in Mosul Grand Mosque, Iraqi News (July 5, 2014), bttp:/ / mon. iraqinews.com/features/urgent-video-isis-releases-abu-baker-al-baghdadi-sermon-mosul-grand-mosque/. Al-Baghdadi was head saying (translated to English), "Allah the Most High says: And I did not create the jinn (demon-possessed humans and animals) and mankind except to worship Me. And He ordered us, Blessed and Exalted be $H e$, to fight His enemies and set out in Jihad in His cause in order to achieve that and establish the Religion. Allah the Most High says: Fighting has been enjoined upon you while it is hateful to you. And He the Most High says: And fight them until there is no fitnah and [until] the religion, all of it, is for Allah. O people, verily the Religion of Allah, Blessed and High be $\mathrm{He}$, will not be established and this purpose for which Allah has created us will be attained except by ruling by the L aw of Allah and legislating to it and establishing the limits (of Allab). This verily will not except by battle and
Jus Cogens (or peremptory norms) refer to "certain fundamental, overriding principles of international law, from which no derogation is ever permitted." ${ }^{37}$ One such Jus Cogens crime is the Crime of Genocide; which all nations have generally accepted as international criminal intent and behavior. The term "genocide" was first used by Raphael Lemkin in his book, Axis Rule in Occupied Europe, published in late 1944. ${ }^{38}$ In 1948following the devastation of the genocidal campaign that sparked World War Two-the young UN defined genocide on a universal level in the 1948 Convention on the Prevention and Punishment of the Crime of Genocide in order to prevent such mass violence whether attempted in times of peace or war. ${ }^{3940}$ However, legal and political scholars feared that getting hung up on genocidal definitions coined in the wake of Nazi gas chambers would miss the opportunity to prevent modern forms of genocide. ${ }^{41}$ Genocidal boundaries must be reestablished to face the threats of nuclear power in the hands

authority." Id. (quoting the Quran, suras 51:56, $21: 26$ \& 8:39); see also Criminal Complaint of the United States against Shannon Conley, at 7, 1 12. "Conley said ISIS was 'going to try to make Syria and Iraq the beginnings of a calipha (ph)." "Id. 37 Richard D. Kearney \& Robert E. Dalton, The Treaty on Treaties, 64 Am. J. Int'l L. 495, 535 (1970). There have been three general categories of Jus Cogens: (1) the threat or use of force in violation of the United Nations' principles, (2) acts or omissions whose suppression is required by international law, and (3) international crimes so characterized by international law. The four basic international crimes (as characterized by international law) are (1) crimes against humanity, (2) war crimes, (3) genocide, and (4) the crime of aggression. Id. Those who violate such norms are condemned as "common enemies of all mankind and all nations have an equal interest in their apprehension and prosecution regardless of their 'state' status or willingness to accede to a treaty," Demjanjuk v. Petrovsky, 776 F.2d 571 (1985).

38 William A. Schabas, Convention for the Prevention and Punishment of the Crime of Genocide, UN Legal Affairs (2008), http:// legal.un.org/avl/pdf/ha/cppcg/cppcg_e.pdf, (stating that even though "genocide" appears in the drafting history of the Charter of the International Military Tribunal, the final text of that instrument uses the cognate term "crimes against humanity" to deal with the persecution and physical extermination of national, ethnic, racial and religious minorities, and therefore, the Genocide Convention was the first true codification of the crime on an international level). 39 Convention on the Prevention and Punishment of the Crime of Genocide, G.A. Res. 260 (III), at art. 1, U.N. Doc. A/78/277 (Dec. 9, 1948) [hereinafter Genocide Convention].

40 See Schabas, supra note 37 (stating that that genocide is a crime under international law which the civilized world condemns). Many scholars argue that the global community considers genocide to be the worst of all international crimes.

41 Gregory Stanton, Create a United Nations Genocide Prevention Focal Point and Genocide Prevention Center, GenocideWatch. net, http://www.genocidewatch.org/images/Prevention-Create_a_ United_Nations_Genocide_Prevention_Focal_Point_and_Genocide_Prevention_Center.pdf (proposing a UN-funded center to identify and prevent modern-day genocidal crimes). 
of extremist organizations. The current elements of genocide-accepted by the 193 member states of the $\mathrm{UN}$ and prosecuted by the International Criminal Court as a crime of universal jurisdiction-include "the deliberate killing of a large group of people, especially those of a particular ethnic group or nation [...] committed with intent to destroy, in whole or part a national, ethnic, racial, or religious group [...] [including] complicity in the commission of act." ${ }^{42}$ As familiar as this egregious criminal ideology may sound to those witnessing the modern scourge of "terrorism" those responsible to produce uniform prosecutorial and preventative methods are paralyzed from producing protective laws by the moral considerations of accepting the perpetrators' ideology. ${ }^{43}$ Definition, in a legal sense, must only "require [...] specifying what it is [one is] examining." "Facing a fact must not be muddled by moral considerations or attempts to clarify the pure intention of the religious ideology from which such violent organizations are operating. During the Crusades and Spanish Inquisition of the 1400s, that religious ideology was enforced Catholicism. Today, it is fundamental Islamic theology. Many Arab leaders in nations that have a majority Muslim population have taken steps to thwart the spread of Islamic militants involved in violent extremism. ${ }^{45}$ The international community must do the same. This is a present-day issue so it must be dealt with squarely, but need not be offensive to any single religion which does not purport to accept the acts of the few.

42 Genocide Convention art. 1; see also Prosecutor v. Jean-Paul Akayesu, Case No. ICTR-96-4-T Judgment (Sept. 2, 1998) (emphasis added).

43 See Goldhagen, supra note Erreur : source de la référence non trouvée, at 8 (stating that "[w]e must consult the corrective lenses of others. We must look at mass killings using impartial criteria. We must keep distinct the tasks of definition ... explanation ... . and moral evaluation ... [and] approach the phenomenon with the willingness to think it through systematically and from the beginning." Id.)

44 See Goldhagen, supra note Erreur : source de la référence non trouvée, at 8.

45 One example of Muslim leaders renouncing such violence under the guise of Islam is Egyptian President Abdel Fattah el-Sisi who stated (in his 2015 New Year's speech in Al Azhar University that addressed top Sunni clerics), "it is not possible that 1.6 billion people [reference to the world's Muslims] should want to kill the rest of the world's inhabitants - that is 7 billion-so that they themselves may live." Ali Sina, The Dilemma of Islamic Terrorism, faithfreedom.org (Jan. 26, 2015), http://www.faithfreedom.org/ the-dilemma-of-islamic-terrorism/. "Sisi did not blame Abu Ghraib, Israel, nor made other silly excuses for Islamic terrorism. He blamed the 'ideology' of it." Id.

\section{The Global Community is Afraid to Call InTEntional Eliminationism "Genocide" and Still Refuses to Objectively, Accurately Label Modern Extermination Campaigns.}

The sovereign community of states failed to prevent the 1994 eliminationist campaign in Rwanda, and despite the tribunals that have addressed the aftermath, it is still failing to prevent mass murder due to misunderstood labels and political correctness. Beginning in March 1994, an extremist group of the Rwandan Hutu population took over a UN peacekeeping mission in Kigali with the intention to annihilate the population of Rwandan Tutsis within their territorial control. ${ }^{46}$ Prior to the commencement of the Hutu extermination agenda, the UN peacekeeping mission leader, Canadian General Roméo Dallaire, received the information of an informant saying that Hutu extremists were planning to kill all Tutsis and diplomats. ${ }^{47}$ Dallaire conjured a plan to raid the military bunkers of the Hutu extremists, but when he informed Kofi Annan at the UN headquarters of his plan, he was immediately told to stand down and that a military raid of any Rwandan group was "outside the scope of his peacekeeping mission." ${ }^{\prime 48}$ Further, the UN told him that his only course of action was to inform the Rwandan government of what Dallaire's informant had relayed to him, despite knowing that many government officials were part of the Hutu plot. ${ }^{49}$ Although

46 Cite (Supported by the "legitimate" Rwandan government, by the way. And by machetes sent from the US, which recognized the legitimacy of the Rwandan government.)

47 Dallaire's book Shake Hands with the Devil is also a good source, but very depressing. I believe he attempted suicide once or twice after returning to Quebec.

48 The Ghosts of Rwanda, PBS Frontline (2014), http://www. pbs.org/wgbh/pages/frontline/shows/ghosts/.

49 The Ghosts of Rwanda, PBS Frontline (2014), http://www. pbs.org/wgbh/pages/frontline/shows/ghosts/. The UN forces in Rwanda had issued at least ten clear warnings to the UN of the 'Hutu power' and plans; During this time, the UN General Assembly passed a resolution entitled "Human Rights and terrorism, G.A. Res. 48/122, U.N. Doc. A/RES/48/122 (1994); "The UN Security Council met in secret after the start of the violence. At this meeting Britain urged that UNAMIR should pull out (and later blocked an American proposal to send in a fact-finding mission when the death toll had reached six figures). Council members resisted admitting 'that the mass murder being pursued in front of the global media was in fact 'genocide.' Genocide involved action no-one wanted to take. Once it was inescapably clear that genocide was indeed going on, it was too late. (The United States, at this point, had actually banned its officials from using the term.)" Information on the Genocide in Rwanda, Peace Pledge Union, http://www.ppu. org.uk/genocide/g_rwanda1.html (last visited Feb. 1, 2015. This 
the UN passed resolutions condemning the violence, even the strongest Security Council resolution purposefully omitted the word "genocide," because if the term "genocide" had been used, the international community would have been legally obliged to act to "prevent and punish" the perpetrators. ${ }^{5051}$ When the targeted population was being destroyed in mass numbers, those in power to help ignored the genocide except for the select men and women who gave everything to save innocent civilian lives, such as Senegalese Captain Mbaye Diagne and American missionary, Carl Wilkins. ${ }^{52}$ With no action from the global community over 800,000 human beings were slaughtered in the course of 100 days. ${ }^{53}$

"The definition of 'genocide' was clearly an international sticking-point [during this time], and because so many were unwilling to classify the atrocities as a 'genocide,' the global community - that had the means and might to stop the violence-remained purposely powerless. ${ }^{54}[\ldots]$. Today, international legal actors working to prevent and prosecute violent extremism refuse to pair the labels of Islamic eschatology with the current campaigns of elimination, and therefore, are committing the same purposeful blindness as the apathetic UN of 1994. The truth is that all mass murder campaigns contain similar elements but very unique intricate motivations and that should be addressed during the prosecution phase. Although Rwanda was "state-sponsored terrorism," (whereas extremist organizations are generally non-state or quasi-state actors), it could have been

website provides a detailed, but concise timeline of the events in Rwanda (Statement by the president of the Security Council, S/ PRST/1994/21. 30 April 1994) ("[SC] calls on the leadership of both parties to condemn publicly such attacks and to commit themselves to ensuring that persons who instigate or participate in such attacks are prosecuted and punished," S/PRST/1994/21).

$50 \quad I d$.

$51 \quad I d$.

52 Id.

53100 Days of Slaughter, PBS, http://www.pbs.org/wgbh/ pages/frontline/shows/evil/etc/slaughter.html (last visited Feb. 1, 2015).

54 Id. (emphasis added). Peace Pledge Union Information on Genocide in Rwanda, Peace Pledge Union, http://www.ppu.org.uk/genocide/g rwanda1.html (last visited July 23, 2014) (stating that "[t]he UN Security Council met in secret after the start of the violence and.. At this meeting Britain urged that UNAMIR should pull out (and later blocked an American proposal to send in a fact-finding mission when the death toll had reached six figures). Council members resisted admitting 'that the mass murder being pursued in front of the global media was in fact genocide': genocide involved action noone wanted to take. Once it was inescapably clear that genocide was indeed going on, it was too late. (The United States, at this point, had actually banned its officials from using the term). prevented by squarely facing the published intentions of the Hutu perpetrators and properly labeling the violence "genocide" rather than hiding behind a wall of "sovereignty" and political correctness. While the Hutu extremists used machetes to commit the acts, modern extremists seek the use and proliferation of nuclear weapons. ${ }^{55}$ As the next section will illustrate, the most widespread and influential extremists (or "terrorists") operate with the intent to commit genocide. ${ }^{56}$

Extremist organizations committing systematic violence are guilty of the crime of genocide and the intent to commit genocide. Following the Islamic Revolution in Iran that ushered in the political rule of Ayatollah Khomeini, Iranian religious leaders decided to create a militant wing of Shi'a Islamic extremists in Lebanon whose foundational ideologies would include viewing Iran as the "vanguard and new nucleus of the leading Islamic State in the world [...] [Abiding] by the orders of [...] Khomeini." ${ }^{57}$ This militant wing of Shi'a extremists became known as Hezbollah and was led primarily by Sheik Hassan Nasrallah. ${ }^{58}$ The global reach of Hezbollah's activities illustrates the expertise of extremists in masking their end goals by "becom[ing] experts in the art of concealing their activities." ${ }^{59} \mathrm{He}-$ zbollah covertly operates throughout Europe, the Middle East, Southeast Asia, Africa, and North America. ${ }^{60}$ Nasrallah, the Hezbollah leader throughout the 1980s, restated Hezbollah's goals saying, "[w]e do not believe in multiple Islamic Republics; we do believe however in a single Islamic world governed by a central government" (the "caliphate" mentioned above). ${ }^{61}$ Hezbollah

\section{Goldhagen, supra note 10.}

56 See Goldhagen, supra note Erreur : source de la référence non trouvée, at 496.

57 Matthew Levitt, Hezbollah: The Global Footprint of Lebanon's Party of God 11-12 (Georgetown University Press, 2013).

58 Id. Hezbollah operates with direct Iranian funding and was trained by Iran's Islamic Revolutionary Guard Corp-Qods force. Id. See also Adam Goldman \& Ellen Nakashima, CIA and Mossad killed senior Hezbollah figure in car bombing, Wash. Post (Jan. 30, 2015, 10:14 PM), http://www.washingtonpost.com/world/national-security/cia-and-mossad-killed-senior-hezbollah-figure-in-carbombing/2015/01/30/ebb88682-968a-11e4-8005-1924ede3e54a_ story.html.

59 Levitt, supra note Erreur : source de la référence non trouvée, at xii. Matthew Levitt spent ten years researching the transnational criminal activities of Hezbollah because information on such organizations is very difficult to find through their covert methods of operations, id.

60 Id.

61 See B.B.C. Monitoring: Al-Manar, Sept. 27, 2002 (cited in Deborah Passner, Hassan Nasrallah: In his own words, frontpagemag. 
believes that Shi'a Muslims possess a duty to create the Caliphate, and therefore, Hezbollah's operations serve Shi'a rebel organizations all over the world whose ideologies mirror their own. ${ }^{62}$

Iran considers Hezbollah its main Shi'a extremist proxy that will ultimately bring about carnage that allows a Shi'a ruled Islamic Caliphate to usher in the return of the Mahdi. ${ }^{63}$ Iran even supports Sunnis when it fits with Iran's geopolitical interests. (keep? Cite?) Hassan Nasrallah, the leader of Hezbollah stated that "America will remain the nation's chief enemy and the greatest Satan [...] [and that] Israel will always be, for us, a cancerous growth that needs to be eradicated." ${ }^{64} \mathrm{He}$ continued, stating that likeminded extremist organizations are "not interested in our own personal security [...] [but rather daily hopes] more than anything to be killed for the sake of Allah." ${ }^{\prime 566}$ While its military and terrorist threats currently remain largely unknown, Hezbollah has been a cunning adversary, and prior to September 11, 2001,

com (July 26, 2006), http://archive.frontpagemag.com/Printable. aspx?ArtId=3227).

62 See e.g. Levitt, supra note 111, at 288 (stating that throughout the 1990s, Hezbollah documented its strategic support of radical Shi'a groups in Tunisia, Kuwait, Saudi Arabia, Egypt, Pakistan, and Yemen). It would not be surprising to discover that Hezbollah's significant resources helped to fund and prepare for the military coup in Yemen where Shia extremist Houthi group ousted the Yemeni Parliament and President.

63 Id. at 8-9.

64 B.B.C. Monitoring: Al-Manar, Hassan Nasrallah, supra note 116.

65 Levitt, supra note Erreur : source de la référence non trouvée, at 7 (discussing Hezbollah's media outlet in Lebanon: Al-Manar TV program).

66 Id. at 288. Since 2012, the United States has also seen a resurgence of activity by Iran's Islamic Revolutionary Guard Corps' Qods Force (IRGC-QF), the Iranian Ministry of Intelligence and Security (MOIS), and Tehran's ally Hezbollah; On January 23, 2013, the Yemeni Coast Guard interdicted an Iranian ship carrying weapons and explosives likely destined for Houthi rebels, U.S. State Department Country Reports on Terrorism, April 2014, http://www.state.gov/r/pa/prs/ps/2014/04/225406.htm (last visited Feb. 7, 2015) (emphasis added to show Iranian and Hezbollah involvement in recent Houthi takeover in Yemen). On February 5, 2013, the Bulgarian government publically implicated Hezbollah in the July 2012 Burgas bombing that killed five Israelis and one Bulgarian citizen, and injured 32 others, id. On March 21, 2013, a Cyprus court found a Hezbollah operative guilty of charges stemming from his surveillance activities of Israeli tourist targets in 2012, id. And on December 30, 2013, the Bahraini Coast Guard interdicted a speedboat attempting to smuggle arms and Iranian explosives likely destined for armed Shia opposition, id.; See also Isabel Kershner \& Anne Bernard, Missile Attack kills 2 Israeli soldiers near Lebanon: Hezbollah claims responsibility, N.Y. Times (Jan. 28, 2015). http:// www.nytimes.com/2015/01/29/world/middleeast/israel-lebanonhezbollah-missile-attack.html?_r $=0$.
Hezbollah had targeted and killed more Americans than any other modern terrorist organization. ${ }^{67}$

Next, the Islamic Resistance Movement (known more commonly as Hamas) began its operations in the Gaza Strip in 1986 as an organization intent upon destroying the State of Israel and replacing the territory known as Israel with Palestine once all Israelis were killed or captured, or deported. ${ }^{68}$ The goal of Hamas remains the desire to "conquer evil, break its will, and annihilate it." ${ }^{69}$ Hamas identifies "evil" as the nation-state of Israel and its allies. ${ }^{70}$ Merriam-Webster defines annihilate as "(1) to destroy something or someone completely, (2) to cause to cease to exist, (3) to reduce to nothing." ${ }^{\prime 1}$ The annihilation of an entire nation and religion is at the forefront of Hamas' Charter and Covenant which fostered its initial creation. ${ }^{72}$ Hamas was voted into political power in the Gaza Strip in 2006 by promising civilians access to water, but since then has utilized its extensive war chest to plan rocket launches and declare war against the State of Israel targeting Israel's civilians and using its own civilians as bait to gain international sympathy and garner universal support against Israel. ${ }^{7374}$ Hamas' opinion towards peace

67 Levitt, supra note Erreur : source de la référence non trouvée, at 358 (stating that Hezbollah likely went underground for planning once America's "War on Terror" sought to annihilate Osama bin Laden's al-Qaeda).

68 See e.g. Dali Halevi \& Elad Benari, Hamas Marks Independence Day with Genocide Video, Israel Nat'l News (July, 2014) (showing a video and what they desire to do with Israeli citizens that are not murdered); See also Caroline Alexander, Hamas Releases End of Hope Video to Mark Israel Independence, Bloomberg News (May 6, 2014, 3:53 PM), http://www.bloomberg.com/news/2014-05-06/ hamas-releases-end-of-hope-video-to-mark-israeli-independence. html.

69 The Charter of the Islamic Resistance Movement, chap. 2, art. 9, trans. Muhammad Maqdsi, available at http://www.palestinestudies.org/files/pdf/jps/1734.pdf (last visited Nov. 11, 2014) [hereinafter Hamas Charter]. "The nation of truth is absent and the nation of evil has been established; as long as Islam does not take its rightful place in the world arena everything will continue to change for the worse.” Id. (citing The Quran, Sura 2:251).

70 Id.

71 "Annihilate" Definition, Merriam-Webster Dictionary, http:// www.merriam-webster.com/dictionary/annihilate (last visited Feb. 11, 2015).

72 See Hamas Charter, supra note 124.

73 See id., art. 16 (emphasis added) (stating that Hamas believes their goal is to "train the Muslim generation in our area, an Islamic training that depends on ... careful study of the enemy's ability, current events, and new trends, studying the analysis and commentaries on it'). (to what end?) Hamas' mode of operation is written in their charter to know political trends and that media and the UN will report civilian casualties, Hamas Charter art.

74 Hamas has not only conducted violent strikes against the state 
initiatives is codified in their charter:

[International peace] conferences are nothing but a form of enforcing the rule of the unbelievers. There is no solution to the Palestinian Problem except by Jihad. The initiatives, options, and international conferences [on establishing peace in Palestine and a two-state solution with Israel] are a waste of time and a kind of child's play. ${ }^{75}$

Several journalists working in Gaza during a time of conflict with Israel noted that it is "undisputable that Gaza militants [members of Hamas Al-Qassam Brigade] operate in civilian areas, draw return fire to civilian structures, and [...] benefit in the diplomatic arena from the rising casualties [of their own people]." ${ }^{\prime 76}$ The journalists also noted that Hamas encouraged its residents not to flee their homes when Israel had warned Palestinian residential areas that there was an impending strike. ${ }^{77}$ Further, although Hamas "prepared extensively for war," it did not build any civilian bomb shelters but rather utilized civilian locations and hospitals as areas to conduct media interviews in direct violation of the Geneva Convention. ${ }^{78}$ Even as the official elected representative of the Palestinian civilians, Hamas' goal has not shifted to caring for their civilian population, but remains intent on annihilating Israel and tarnishing Israel to the international community despite the loss of Palestinian lives. After over 2,000 Palestinians had been killed in Hamas' war against Israel ${ }^{79}$, Hamas still

of Israel or her sympathizers (August 2014 of Hamas carrying out public executions of Palestinian civilians they believed were allied with Israel) but also on other sects of Islamic leadership in the land of Palestine ("Jund Ansar Allah is, or was, an armed Salafist jihadist organization in the Gaza Strip. On August 14, 2009, the group's spiritual leader, Sheikh Abdel Latif Moussa, announced during Friday sermon the establishment of an Islamic emirate in the Palestinian territories attacking the ruling authority, the Islamist group Hamas, for failing to enforce Sharia law. Hamas forces responded to his sermon by surrounding his Ibn Taymiyya mosque complex and attacking it. In the fighting that ensued, 24 people (including Sheikh Abdel Latif Moussa himself), were killed and over 130 were wounded." (Al-Quds Al-Arabi (London), August 19, 2009.).

75 Hamas Charter, supra note 124, art. 13.

76 Simon Plosker, Foreign Journalists Acknowledge Hamas' Human Shields Tactics, Honest Reporting (July 23, 2014), http://honestreporting.com/foreign-journalists-acknowledge-hamas-humanshields-tactics/.

77 Id.

78 Id.; see also Hamas backers spend fortunes on rockets and tunnels while Gazans live in misery, Fox News (Aug. 8, 2014) http:// www.foxnews.com/world/2014/08/08/hamas-backers-spend-fortunes-on-rockets-and-tunnels-while-gazans-live-in-misery/.

79 See Hamas admits kidnapping of Israeli Teens, USA Today (Aug. 21, 2014), http://www.usatoday.com/story/news/ world/2014/08/21/hamas-kidnapping-israeli-teens/14406827/ (displaying that the event which triggered the 2014 conflict was, in- declared victory in the 2014 Gaza conflict. ${ }^{80}$ The deaths of civilians, including children, are no concern to Hamas as was observed in an article during the 2014 Gaza-Israeli: ${ }^{81}$

Hamas on Tuesday rejected an Egyptian ceasefire proposal that was supported by Western governments and the Arab League and had been accepted by Israel.

Why would Hamas insist on continuing the fight when it is faring so poorly? The only plausible answer is stomach-turning: The Islamic movement calculates that it can win the concessions it has yet to obtain from Israel and Egypt not by striking Israel but by perpetuating the killing of its own people in Israeli counterattacks. More than 200 people, including a number of children, have already died in Gaza; Hamas probably calculates that more deaths will prompt Western governments to pressure Israel to grant Hamas's demands. ${ }^{82}$

The civilians living in Hamas-controlled territories

deed, perpetuated by Hamas).

80 The Reasons Why Israel's Military Is In Such A Tough Fight, NPR (July 25, 2014, 10:52 PM), http://www.npr.org/blogs/ parallels/2014/07/24/334893877/the-reasons-why-israels-military-is-in-such-a-tough-fight; See also the Geneva Conventions (which ones) "The parties to a conflict shall not direct the movement of the civilian population or individual civilians in order to attempt to shield military objectives from attacks or to shield military operations" "the presence or movements of the civilian population or individual civilians shall not be used to render certain points or areas immune from military operations, in particular in attempts to shield military objectives from attacks or to shield, favour or impede military operations."

81 See Hamas is playing a dangerous game with Gazan lives, Wash. Post (July 15, 2014), http://www.washingtonpost.com/ opinions / hamas-is-playing-a-dangerous-game-with-gazanlives/2014/07/15/cc5f101e-0c3b-11e4-8c9a-923ecc0c7d23_story. html?wpmk=MK0000203 (noting that one must wonder why Hamas would refuse to honor or recognize a cease fire with Israel when their civilians were faring so poorly against the IDF); see also Plosker, Hamas' Human Shields Tactics, supra note Erreur : source de la référence non trouvée (stating that even when warnings from Israeli officials to evacuate reach Palestinian civilians, oftentimes, the innocent cannot escape because Hamas-as an elected representative of the Palestinian civilians-blocks radio broadcasts or tells their fleeing civilians that Israel is blocking the exits or that they cannot leave through such an exit); See Rosen, Targeting Enemy Forces in the War on Terror: Preserving Civilian Immunity, supra note Erreur : source de la référence non trouvée (stating that the Protocol I to the Geneva Conventions of 1949 is fundamentally flawed and that the current law governing targeting is fundamentally defective; it allows terrorist and insurgent groups to gain strategic and tactical advantages through their own noncompliance with the law and their adversaries' observance of it).

82 Hamas is playing a dangerous game with Gazan lives, Wash. Post (July 15, 2014), http://www.washingtonpost.com/ opinions / hamas-is-playing-a-dangerous-game-with-gazanlives/2014/07/15/cc5f101e-0c3b-11e4-8c9a-923ecc0c7d23_story. html?wpmk=MK0000203. 
know this as evidenced by the drop in positive ratings according to recent polls conducted in Gaza, ${ }^{83}$ and the world now understands the extent Hamas was willing to go to perpetuate international condemnation against Israel given that almost 2,200 people died as a result of Hamas' refusal adopt the proposed cease-fires. Regardless of one's stance on the situation involving Israel and Palestine, the intent to exterminate any people, ethnic group, nationality, or religion directly conflicts with the laws prohibiting genocide and crimes against humanity, which have been signed and acceded to by all 196 member and observer states of the UN-including the State of Palestine in $2014 .^{84}$

Quasi-state actors such as Hamas and Hezbollah have been able to gain forms of political power in their respective territories. However, both organizations continue to have the shared goal of annihilating entire nations or people groups using violence or extermination. ${ }^{85}$ To these organizations, such goals outweigh all desire to abide by international laws and respect for human rights and dignity and therefore, the definitions of modern-day terrorist organizations should fit their stated intent and refuse to allow them political office over civilians with such eliminationism intentions. The next section will cover non-state organizations whose similar intentions span across borders and have no legitimate state alliance.

83 See Muslims Worldwide Fear the Rise of Islamic Extremism: Pew Survey, Huffington Post (Updated July 23, 2014, 11:59 AM), http://www.huffingtonpost.com/2014/07/02/muslims-againstextremism-pew-survey_n_5551693.html (showing that "Hamas has fallen out of favor in Palestine since 2007, when 62 percent of Palestinians viewed them positively. Now, in 2014, only 35 percent reported a favorable opinion, with 53 percent on record as having an unfavorable opinion. In the Gaza Strip, which is controlled by Hamas, 63 percent of people have a negative opinion of the group, which is up from 2013, when only 54 percent reported unfavorable views," id.); Mariano Castillo, Chelsea J. Carter \& Salma Abdelaziz, Captured, Killed or missing? Fate of Israeli soldier remains unknown, CNN (Aug. 6, 2014, 12:02 PM), http://www.cnn.com/2014/08/01/ world/meast/mideast-crisis/ (speaking of how Hamas broke a peaceful ceasefire in 90 minutes with a suicide bomber placing their civilians in more danger exposing them to defensive fire).

84 List of Accession or Ratification to the Genocide Convention, UN Treaties, available at https://treaties.un.org/Pages/showDetails.aspx?objid $=0800000280027 \mathrm{fac}$ (last visited Feb. 1, 2015) (displaying that Palestine acceded to the Genocide Convention in 2014). 85 See William Booth, While Israel held its fire, the militant group Hamas did not, Wash. Post (July 15, 2014), http://www.washingtonpost.com/world/middle_east/while-israel-held-its-fire-the-militant-group-hamas-did-not/2014/07/15/116fd3d7-3c0f-4413-94a92ab16af1445d_story.html.
The notion of violent Jihad carried out by extremist groups was not widespread until the mid to late twentieth century, when Osama bin Laden-whom many consider to be the founder of transnational violent jihad-founded the movement. ${ }^{86}$ After fighting and defeating the Soviet forces in Afghanistan in the 1980s, bin Laden moved back to his home, Saudi Arabia to build up an army that would seek to fight and eradicate "un-Islamic" governments by purging. ${ }^{87} \mathrm{Al}$-Qaeda also worked to forge alliances with other organizations such as the "International Islamic Front for Jihad against the Jews and Crusaders," Hezbollah, the Harakat ul-Ansar, and others. ${ }^{88}$ (Bin Laden established training base in Sudan around 1992, at the same time as Sudan had Iranian revolutionary guards training forces in the country. I believe Bin Laden was linked to the attempted assassination of Hosni Mubarak in Addis Ababa in 1995.)

Suleiman Abu Geith, Al-Qaeda's spokesman stated, at one point, that Al-Qaeda had "the right to kill 4 million Americans-2 million of them children-and to exile twice as many and wound and cripple hundreds of thousands." ${ }^{89}$ This intent displays the beliefs of modern jihadists that ("peaceful") Muslims who follow the Quran, live good lives, and believe in peace, family, and stability are to be declared "apostates" and should be condemned to Hell. A more pragmatic way of phra-

86 Joel C. Rosenberg, Inside the Revolution 8, 108-09 (Tyndale House Publishers, Inc., 2011).

87 Id. at 109; See also Al-Qaeda, Infoplease.com, http://www. infoplease.com/spot/al-qaeda-terrorism.html\#ixzz3DUUbDNkY (last visited Nov. 9, 2014).

88 Id.

89 Suleiman Abu Gheith, In the Shadow of Lances, MEMRI Special Dispatch Series-No. 388 (June 12, 2002), www.memri.org/ bin/articles.cgi? ID=sp38802\#_edn1; At another point, in response to the spread of al-Qaeda and violent jihad, Hassan al-Tarabi (the religious leader in Sudan) issued a fatwa that "Muslims who try to question or doubt the Islamic justifiability of [violent] jihad are hereby classified as 'hypocrites' who are no longer Muslims, and also 'apostates' from the religion of Islam; and they will be condemned permanently to the fire of Hell." This statement comes from the religious leader of Sudan--the country that housed the first and primary headquarters of al-Qaeda and recently sentenced a Christian mother to death for "apostasy," displaying the intended consequences of those whom the extremists consider "apostates." Meriam Ibrahim Meet Pope Francis after Escaping Sudan, NBC News (July 24, 2014), http://www.nbcnews.com/news/world/christianmeriam-ibrahim-meets-pope-francis-after-escaping-sudan-n163681. "Because [Miriam Ibrahim also] married a Christian, she was also sentenced to 100 lashes for apostasy," id. She was forced to take her 20-month-old son into her cell in a Sudanese prison for women and gave birth to her second child, Maya, while her legs were in shackles," id. 
sing their intent is global domination and control over all those whom they consider enemies of Allah. Al-Qaeda's primary alliances-which also included representatives of the government of Iran-maintained the common purpose of working together against their perceived enemies: the United States, Israel, and the nationals of both states. ${ }^{90}$ All U.S. nationals are targets for attack and mass casualties, and al-Qaeda has equipped — through funding or donating weapons — other extremist organizations who share the same intent to target an entire nationality. Today, al-Qaeda operates through various branches. Although some are of more imminent concern, one of the most dangerous is al-Qaeda in the Arabian Peninsula (AQAP) that mainly operates in Yemen and is purported to gain a stronger foothold since its main area rival—-the Shiite extremist Houthis group-has ousted the Yemeni government, leaving AQAP the only other governing "option" in the country. ${ }^{91}$ Further, the AQAP has been forging ties with the Islamic State (known more commonly as ISIS or ISIL) who has started training and recruiting in certain parts of Yemen. ${ }^{92}$

With the rise of ISIS, ironically, al-Qaeda has been quick to publically denounce the ISIS reign, but the underpinnings of their operation parallel those of ISIS seeking the annihilation of certain (national groups/ states) ethnic or religious groups. ${ }^{93}$ The global community is wise to ignore the attempts of al-Qaeda to separate themselves from ISIS as its self-proclaimed leader, Abu Bakr al-Baghdadi, rose from al-Qaeda's roots and only recently renamed the group the Islamic State of Iraq and Syria or "The Levant." mly established in al-Qaeda's theology. ${ }^{95}$ Many of the

90 Bin Laden: al Qaeda, PBS.org, http://www.pbs.org/wgbh/ pages/frontline/shows/binladen/who/alqaeda.html (last visited Aug. 31, 2014).

91 Tim Lister \& Paul Cruickshank, Yemen takeover threatens downward sectarian spiral; al Qaeda set to benefit, CNN (Jan. 21, 2015, updated 6:09 PM), http://www.cnn.com/2015/01/21/world/yemen-houthis-alqaeda/.

92 Id.

93 See Amir Abdallah, URGENT Video: ISIS releases Abu Bakr al-Baghdadi sermon in Mosul Grand Mosque, Iraqi Nat'l News (July 5, 2014), http://www.iraqinews.com/features/urgent-video-isisreleases-abu-bakr-al-baghdadi-sermon-mosul-grand-mosque/.

94 Colin Freeman, The Jihadist behind the takeover of Mosul and how America let him go, Telegraph.co.uk (June 11, 2014, 12:13 PM BST), http://www.telegraph.co.uk/news/worldnews/middleeast/ iraq/10891700/Iraq-crisis-the-jihadist-behind-the-takeover-of-Mosul-and-how-America-let-him-go.html.

95 Id.; See also Obama Iraq Combat Mission Ends by Aug. 31, Newsday (Feb. 27, 2009, 6:23 PM), http://www.news- terrorists that were freed from the American prison in Iraq-Abu Ghraib-were believed to have headed to Syria, where they proved decisive in turning al-Qaeda into the pre-eminent rebel movement, now known as ISIS, in the fight against Syrian President Bashar Assad. ${ }^{96}$ (more substance for this assertion) A Middle Eastern news source stated that, as of June 2014, ISIS was composed of several factions of extremist organizations including a "rebranded al-Qaeda," Sadam Hussein's Baath Party, and other Sufi Islamists. ${ }^{97}$

The group currently has about 7,000 fighters in northern Syria, including volunteers from Britain, Canada, the United States, and Europe. ${ }^{98}$ Baghdadi has called on Muslims around the world to flock to territories under his control to fight and build an Islamic state. ${ }^{99}$ In a recording posted online, Baghdadi declared he wants to turn the enclave his fighters have carved out in the heart of the Middle East into a "magnet for militants." (State what legitimate

day.com/news/nation/obama-iraq-combat-mission-ends-byaug-31-2010-1.895115. "The new al-Qaeda was rebranded in 2006 as the Islamic State in Iraq (ISI), id.; see also Joseph Klein, Leader of jihadist onslaught released, Frontpage Mag (June 16, 2014), http:// www.frontpagemag.com/2014/joseph-klein/leader-of-jihadist-onslaught-in-iraq-released-on-obamas-watch/.

96 The Jihadist behind the takeover of Mosul and how America let him go, see supra text accompanying note 147.

97 Obama's "up to 300 US military advisers" won't stop ISISSunni entrenchment in Iraq, DEBKAfile (June 19, 2014, 9:13 PM) (stating that the Islamists advancing on Baghdad are not one, but two armies: The Al Qaeda element has been joined by a hodgepodge of Sufi groups, Saddam Hussein's old Baath Party guard, and UStrained Sunni Awakening Council tribes).

98 Id.; Such has been ISIS's brutality in Syria that it has even alienated other al-Qaeda affiliated groups, and prompted numerous reports that it is at least partly a creation of President Assad's intelligence services, designed to discredit and disunite the rebel movement (id) That does not square with Baghdadi's known-hatred of Shia Muslims, the sect to which Mr. Assad belongs. Like most other al-Qaeda extremists, Baghdadi views Shias as apostates, be they those in Syria or those in the Shia-majority government in Baghdad, id.; see also Leila Fadel, U.S. hands over Tariq Aziz, other detainees to custody of Iraqi government, Wash. Post (July 14, 2010), http:// www.washingtonpost.com/wp-dyn/content/article/2010/07/14/ AR2010071401604.html.

99 Shelby Lin Erdman, Who is the ISIS? CNN (June 12, 2014), http://www.cnn.com/2014/06/12/world/meast/who-is-the-isis (stating that Baghdadi served four years in a U.S. prison camp in Iraq where he almost certainly developed a network of contacts and honed his ideology before being released in 2009).; See also Mohammed Tawfeeq \& Hamdi Alkhshali, Report: ISIS kills 270 at Syrian gas field, CNN (July 18, 2014), http://www.cnn.com/2014/07/18/ world/meast/iraq-isis-christians-threatened/.

100 Amir Abdallah, URGENT Video: ISIS releases Abu Bakr alBaghdadi sermon in Mosul Grand Mosque, Iraqi Nat'l News, supra note 21. 
is) The goal of the Islamic State is mass destruction and imperialization of legitimate states and individuals through violence and carnage. ${ }^{101}$ The threat of the ISIS has been underestimated by United States and now has spread beyond the boundaries of any manageable crisis. ${ }^{102}$ The Secretary General of the OIC, Iyad Ameen Madani, has condemned the actions of ISIS against innocent Muslim and Christian Iraqi citizens in Mosul and Nineveh including the forced deportation under the threat of execution; thus further tearing apart the social fabric of the Iraqi people. ${ }^{103}$ In the United States, the Federal Bureau of Investigation arrested a woman named Shannon Conley, who had a significant relationship and knowledge of ISIS. She was detained before leaving the country and her intelligence provided information useful in understanding the methods of ISIS recruiting. ${ }^{104}$ Conley stated she has no interest in doing humanitarian work and that violent Jihad was the only answer to correct the wrongs against the Muslim world." 105 This shows that extremist organizations also feed on the sympathetic sentiments of young westerners - to protect the plight of Muslims against injustice even though most Muslims have no desire to wage violence or commit murder. ${ }^{106}$ According to Conley, it was acceptable to attack or kill westerners when engaged in "defensive Jihad" since ISIS operates under its own truth that all targets of violence and murder are acceptable if they abide by "man-made laws that are not grounded in [Allah's] law."107 This intent justifies the murder of almost any legally

101 Facing fines or death, Christians flee Mosul, CNN (July 19, 2014), http://www.cnn.com/2014/07/19/world/meast/christiansflee-mosul-iraq/.

102 See e.g. ISIS magazine claims group has enslaved and sold Yazidi women and kids, Fox News (Oct. 13, 2014), http://www. foxnews.com/world/2014/10/13/isis-magazine-claims-group-hasenslaved-and-sold-yazidi-women-and-kids/.

103 OIC Condemns ISIS threats and forced displacement of Christians in Iraq, Org. of Islamic Cooperation (July 17, 2014), http://www.oic-oci.org/oicv2/topic/?t_id=9241\&t_ ref $=3695 \& l a n=$ en. Madani added that this forced displacement is a crime that cannot be tolerated; and that the practices of ISIS have nothing to do with Islam and its principles that call for justice, kindness, fairness, freedom of faith and coexistence, id.

104 Michael Martinez, Ana Cabrera \& Sara Weisfeldt, Colorado woman gets 4 years for wanting to join ISIS, CNN (Jan. 24, 2015, updated 9:29 AM), http://www.cnn.com/2015/01/23/us/colorado-woman-isis-sentencing/index.html.

105 FBI Criminal Complain Shannon Conley, at 5 (7).

106 FBI Criminal Complain Shannon Conley, at 6 (8).

107 FBI Criminal Complain Shannon Conley,. at 4. innocent individual they deem an apostate to their religious doctrine.

Next, the media has generally ignored the lesser-funded extremist organizations that fully support ISIS's rise, such as Boko Haram. ${ }^{108}$ Operating primarily in Nigeria, Boko Haram rose to infamy with the kidnapping and exploitation of nearly 300 young school-girls. ${ }^{109}$ While the world watches IS, Boko Haram declared an Islamic Caliphate in Nigeria amidst a government that has remained powerless to stop this extremist group. ${ }^{110}$ Nigerian government troops have fled while Boko Haram implements its harsh version of Islamic law on approximately 3 million civilians, which includes ongoing beheadings and forced induction of children into its own military forces, in direct violation of Geneva Conventions and international legal principles. ${ }^{111}$ The group's self-proclaimed leader, Abubakar Shakau, addressed the community in Gwoza - a city that Boko Haram conquered - claiming to be responsible for over 1,000 deaths of the "mostly Christian community" in only one day's time. ${ }^{112}$ Shakau is one of the prominent Islamic jihadi leaders that welcomed the rise of ISIS and has emulated al-Baghdadi's brutal reign. ${ }^{13}$ Although the Cairo Declaration in Islam contends that "taking hostages under any form or for any purpose is expres-

108 See Elias Meseret, Africa agrees to send 7,500 troops to fight Boko Haram, Assoc. Press (Jan. 31, 2015 2:24 PM EST), http:/ / bigstory.ap.org/article/8199f64eda1b475b873164943ec84e6d/africaagrees-send-7500-troops-fight-boko-haram.

109 Robert Windrem, While the World Watches ISIS, Boko Haram declares its own Caliphate ion Nigeria, NBC News (Sept. 15, 2014, 4:39 AM), http://www.nbcnews.com/storyline/missingnigeria-schoolgirls/while-world-watches-isis-boko-haram-declaresits-own-caliphate-n202556.

110 Robert Windrem, While the World Watches ISIS, Boko Haram declares its own Caliphate ion Nigeria, NBC News (Sept. 15, 2014, 4:39 AM), http://www.nbcnews.com/storyline/missingnigeria-schoolgirls/while-world-watches-isis-boko-haram-declaresits-own-caliphate-n202556.

111 Robert Windrem, While the World Watches ISIS, Boko Haram declares its own Caliphate ion Nigeria, NBC News (Sept. 15, 2014, 4:39 AM), http://www.nbcnews.com/storyline/missingnigeria-schoolgirls/while-world-watches-isis-boko-haram-declaresits-own-caliphate-n202556

112 Robert Windrem, While the World Watches ISIS, Boko Haram declares its own Caliphate ion Nigeria, NBC News (Sept. 15, 2014, 4:39 AM), http://www.nbcnews.com/storyline/missingnigeria-schoolgirls/while-world-watches-isis-boko-haram-declaresits-own-caliphate-n202556

113 Robert Windrem, While the World Watches ISIS, Boko Haram declares its own Caliphate ion Nigeria, NBC News (Sept. 15, 2014, 4:39 AM), http://www.nbcnews.com/storyline/missingnigeria-schoolgirls/while-world-watches-isis-boko-haram-declaresits-own-caliphate-n202556 
sly forbidden," 114 Boko Haram has gone widely unpunished. ${ }^{115}$

The desire of Boko Haram to join and celebrate the work of ISIS highlights the necessity for the global community to codify transnational terrorism in order to prevent a transnational genocidal alliance of extremist organizations intent on annihilating those they deem to be apostates or evil..$^{116}$ While most international conventions seeks to hold "state" actors responsible for "state-sponsored" criminal acts, the chart displayed shows that militant groups which align with no legitimate state still commit mass atrocities that the global community denounces through international conventions. These extremist organizations must be held accountable to the same international standards in a court of universal jurisdiction. ${ }^{117}$ While such organizations are not parties to the treaties or conventions, this should not preclude them from being tried as international criminals. Innocent lives and civilian well-being are not as important to these extremist organizations as the end goal of building the Islamic Caliphate (or global government) by "cleansing" humanity of all "apostate" Muslims, Jews, Christians, and even entire nations (such as Israel or the United States). ${ }^{118}$

The gravest danger this world faces is modern extremism perpetuated by radical Islamists. ${ }^{119}$ These orga-

114 Boko Haram's treatment of Captured Nigerian girls detailed in new report, Fox News (Oct. 27, 2014), http://www.foxnews. com/world/2014/10/27/boko-haram-treatment-captured-nigerian-girls-detailed-in-new-report/; see also Cairo Declaration on $\mathrm{Hu}$ man Rights in Islam, art. 21 "(a) Human beings are born free, and no one has the right to enslave, humiliate, oppress or exploit them, and there can be no subjugation but to Allah the Almighty."

115 Windrem, supra note Erreur : source de la référence non trouvée.

116 Goldhagen, supra note Erreur : source de la référence non trouvée, at 293-96.

117 In the next section, the crimes that militant organizations carry out on a systematic basis will be highlighted. See United States Department of State: National Consortium for the Study of Terrorism and Responses to Terrorism: Annex of Statistical Information, http://www.state.gov/j/ct/rls/crt/2013/224831.htm (last visited Feb. 16, 2015).

118 Look into this: Often it seems innocent lives and civilian wellbeing are not as important as State goals of maintaining security and order and repressing dissent. E.g. South Africa from 1948-1994 or even US maintaining security by baiting previously innocent civilians into terrorist plots such as Portland Christmas bombing plot a few years ago created by FBI.

119 But cf. Goldhagen, supra note Erreur : source de la référence non trouvée, at 97-99 (which displays that unlike modern extremist groups who know the human nature of their victims, Hitler's forces and Hutu militants would demonize their enemies to garner nizations are well aware of the human nature of their targets: whether they be Muslims, Jews, Christians, or others, and yet they still perpetuate the mass murder without needing to dehumanize their victims for justification. According the Pew Research Center there are approximately 2.2 billion Christians in the world; 1.6 billion Muslims ( $99 \%$ of whom would be considered "moderate" and therefore apostate Muslims to the extremist Salafists or other radical Islamist factions); and 13.9 million Jews. ${ }^{120}$ If the promulgated goals of modern-day extremist organizations are evaluated in realistic data, this means that in order to "cleanse" this world bringing about the final Caliphate, radical groups are willing and poised to kill (according to their specific Charters) any or all of the following populations: (1) 1.58 billion Muslims that don't believe in violent jihad and extremism; (2) 320 million people living in the United States (the "Great Satan") ${ }^{121}$; (3) 8.3 million people living in Israel ${ }^{122}$; (4) 2,213,900,000 Christians and Jews; and worst of all (5) 3,813,900,000 "apostate" Muslims, Christians, and Jews in total. If ever there was a number that indicated the intent to commit genocide, nearly 4 billion human lives (over half of the world's current population ${ }^{123}$ ) is it.

\subsection{Unresolved Issues; Gaps in the System; Pro- posed Changes.}

Rather than learning from the patterns of historical precedent to prevent brutal atrocities, the global community appears to prioritize sovereignty over protecting the defenseless. ${ }^{124}$ Right now the biggest gap in the global legal system revolves around the interplay between maintaining state sovereignty while attempting to quell a threat that knows no boundaries. Upholding state sovereignty and preventing bloodshed do not have to be mutually exclusive. The problem with maintaining state

support).

120 Pew-Templeton Global Research Futures Project of 2012, http://www.globalreligiousfutures.org/questions (last visited Feb 1, 2015).

121 U.S. and World Population Clock, http://www.census.gov/ popclock/ (last visited Feb. 1, 2015).

122 On eve of 2015, Israel's population hits 8.3 million, jpost Jan. 16, 2015)http://www.jpost.com/Israel-News/Culture/Oneve-of-2015-Israels-population-hits-83-million-386178.

123 U.S. and World Population Clock, supra note 185.

124 At least, Sovereignty seems more important than preventing murder until after innocent blood has been shed as was evidenced in the Rwanda genocide and resolutions claiming to uphold sovereignty. 
sovereignty in spite of the mass threat to the powerless civilians is that it leaves those who could rescue the innocent paralyzed beyond the tipping point where too many lives have been taken to ignore the situation any longer. ${ }^{125}$ The truth is that those who do not learn from the past are doomed to repeat it. Now, this does not mean that sovereignty is not to be recognized and protected. It means that upholding sovereignty over innocent bloodshed can no longer be a foundational or practical aspect of a global community that seeks "international peace and security." ${ }^{126}$ The main threat to international peace, security, and stability today-as stated above - is transnational terrorism; which is modern day genocide to an extent this world has yet to witness.

Those who commit acts of transnational terrorism must be put on explicit notice that perpetual violence carried out by non-state aggressors will be prosecuted under international law by legitimate courts who uphold the rule of law. ${ }^{127}$ If the legitimate state governments do not accept that modern extremism is the equivalent of genocide, then these violent organizations will defeat legitimate judicial systems by committing atrocities with impunity. To understand the roots of an organization, one must look objectively at its promulgated goals whether they are based in a religion or a secular ideology. ${ }^{128}$ This is a critical first step for lawmakers and officials in attempting to prevent further mass murder by transnational terrorists. ${ }^{129}$ The proliferation of weapons of mass destruction and nuclear materials make any illegitimate group-no matter how small—a real threat to civilians. ${ }^{130}$ These groups will continue to act with impunity by committing terrorist acts under a generic term which remains universally undefined. The

125 See Goldhagen, supra note Erreur : source de la référence non trouvée, at 11, 26-27.

126 UN Charter preamble; see also U.N. Charter art. 2, para. 4.

127 See Protocol Additional to the Geneva Conventions of 12 August 1949 relating to the Protection of Victims of Non-International Armed Conflicts, June 8, 1977 (discussing how fears of state sovereignty infringement has prevented states from enacted procedures to implement Geneva conventions regarding the protection of civilians in a conflict that is not of an international character. This shows that state sovereignty fears often limit prevention of atrocities against civilians on various levels, id.)

128 Goldhagen, supra note Erreur : source de la référence non trouvée, at 25-27.

129 Id. at 588 (discussing the importance of preventative measure to reduce eliminationist and mass murder campaigns).

130 Id. at 511-12 (stating how the proliferation of nuclear materials to non-state actors makes their existence and intended goals a much greater, imminent threat to international stability, peace, and security of the global population). extremists' system of illegitimate power struggles seeks to overpower the legitimate governmental structures of the "state" system which could undoubtedly result in the tearing down of the legitimate entities who are paralyzed to prosecute transnational crimes.

Today the word "terrorism" is used to refer to any form of violence that cannot be categorized, no matter how egregious the atrocities and no matter what the intent of the perpetrators has become. ${ }^{131}$ The current test for determining terrorism is more of an "impact test." One asks what the impact of the violent act had on the civilians. However, to prevent terrorist acts, the universal definition should adopt an "intent test."132133 "Islamic terrorists carry out acts of genocidal intent and war against bumanity with impunity as non-state actors because most international conventions criminalizing their actions mainly mandate relationships between states and state officials rather than non-state organizations". ${ }^{134}$ This failure to objectively look at the perpetrator's intent leaves those with the power to prosecute and define the atrocities unable to do so due to the progressive forces that believe such objective methods offends a religious doctrine. ${ }^{135}$ In an excellent article by Asra Nomani, a Muslim American, this paralysis of refusing to align any form of political Islam with modern terrorist acts is a real issue, and one that must be addressed in the quest to define it universally. ${ }^{136}$

131 See Thomas Weigend, The Universal Terrorist, supra note Erreur : source de la référence non trouvée, at 1.

132 But cf. Goldhagen, supra note Erreur : source de la référence non trouvée, at 510 (purporting to classify transnational terrorists as Political Islamists given the misleading identification that such groups solely intend political power, rather than asserting their global domination aspirations).

133 The preceding chart displays only a few of the most notorious "extremist" organizations and offers proof that such organizations are inciting, intending, and carrying out some of the most condemned acts of violence against the global civilians and political communities. Without properly defining the crimes of such actors, the international community has and will be paralyzed to stop the atrocities being committed. The evidence of refusal to adopt such a definition is displayed by the rise of ISIS throughout the Middle East and the number of civilians who have been murdered or retreated into hiding as the world waits by the television for the next move of such atrocious individuals.

134 Thomas L. Friedman, Say it like it is, N.Y. Times (Jan. 20, 2015), http://www.nytimes.com/2015/01/21/opinion/thomasfriedman-say-it-like-it-is.html?_r=0.

135 See e.g. ASEAN Convention on Counter-Terrorism, supra note Erreur : source de la référence non trouvée, preamble, ("Reaffirming that terrorism cannot and should not be associated with any religion, nationality, civilisation or ethnic group.').

136 Asra Q. Nomani, Meet the honor brigade, an organized campaign to silence debate on Islam, Wash. Post (Jan. 16, 2015), http://www.washingtonpost.com/opinions/meet-the- 
It is the largest gap in the current system and the reason that terrorism has yet to be defined and proactively suppressed on a universal level. Nomani writes that,

[t]his is largely because of the rising power and influence of the 'ghairat brigade,' an honor corps that tries to silence debate on extremist ideology in order to protect the image of Islam. It meets even sound critiques with hideous, disproportionate responses. The campaign began, at least in its modern form, 10 years ago in Mecca, Saudi Arabia, when the Organization of Islamic Cooperation - a mini-United Nations comprising the world's 56 countries with large Muslim populations, plus the Palestinian Authority — tasked thenSecretary General Ekmeleddin Ihsanoglu with combating Islamophobia and projecting the "true values of Islam." During the past decade, a loose honor brigade has sprung up, in part funded and supported by the OIC through annual conferences, reports and communiques. ${ }^{137}$

As stated, this is not an article to combat a religion. On the contrary, it has become common knowledge that most religious Muslims do not follow or prescribe, at all, to the philosophy of violence in the name of Allah. ${ }^{138}$ However, the factual reality is that every terrorist group mentioned above as well as those operating in many major cities and threatening the free world all operate under a form of Islam. ${ }^{139}$ In order to define "terrorism" and prosecute the perpetrators, it is necessary to study, understand, and proclaim the mens rea of the offenders without fear of public scrutiny. The "fear" that results from terrorist attacks is not from the "terrorists" themselves, but from the progressive ideologists that use incidents of premediated murder as a platform to condemn all who dare to study the perpetrators by their stated goals. ${ }^{140}$ In order to comprehend the full extent of the extremist threat, it is important to understand the mode of operation and methodology behind the "typical terrorist" actions. Preventative mea-

honor-brigade-an-organized-campaign-to-silence-critics-ofislam/2015/01/16/0b002e5a-9aaf-11e4-a7ee-526210d665b4_story. html (emphasis added).

137 Id.

138 Dean Obeidallah, Are All Terrorists Muslims? It's Not Even Close, The Daily Beast (Jan. 14, 2015), http://www.thedailybeast. com/articles/2015/01/14/are-all-terrorists-muslims-it-s-not-evenclose.html.

139 Quran, Sura 9:73, ("Strive hard against the unbelievers and the hypocrites and be unyielding to them; and their abode is hell, and evil is their destination.").

140 See 'Guns don't kill people, Americans kill people,' Fox News (Nov. 13, 2015), http://www.foxnews.com/entertainment/2013/11/06/michael-moore-guns-dont-kill-people-americans-kill-people/ sures should incorporate a substantial knowledge of the individuals' intent who currently engage in transnational acts of terror.

The UN Office of the Special Adviser on The Prevention of Genocide has stated that " $\mathrm{t}] \mathrm{o}$ prevent genocide and genocidal conflicts, it is critically important to understand their root causes." ${ }^{141}$ Whether the root causes lie within a secular manifesto (such as Hitler's "Mien Kampf”) or a religious doctrine (such as certain sayings of Muhammad found in particular Hadith literature) it is important to understand the root causes of the violence and where it stems from, so that further bloodshed can be foreseen and prevented without fear or denial of a religious tie that the organizations, themselves, profess to follow. ${ }^{142}$ Any uniform attempt extremism should include the creation of tribunals that would have jurisdiction over crimes of genocide carried out by extremists. ${ }^{143}$ "Tribunals are [generally] set up outside the situs of [a] conflict], both because of security concerns and because [] an outside court, staffed largely by outsiders, would have the advantages of impartiality, credibility, and expertise that would be lacking in compromised or decimated national legal systems." ${ }^{144}$ This tribunal will have specific prosecutorial duties and universal jurisdiction so that affected states may appeal for aid, protection, and prosecution. ${ }^{145}$

141 Preventing Genocide: Office of The Special Adviser on The Prevention of Genocide, un.org, http://un.org/en/preventgenocide/adviser/genocide_prevention.shtml (last visited Feb. 9, 2015); See also Geneva Conventions, General introduction to the commentary on Additional Protocol II, which discusses that most noninternational armed conflicts tend to be organized groups operating against a government in a "single state" which limits the applicability of the Geneva Convention principles protecting civilians only to domestic "rebel" groups rather than extremist organizations.

142 See e.g. O’Connell, supra note Erreur : source de la référence non trouvée, at 520 (discussing the difficulties in defining and prosecuting terrorism).

143 For an example of a current international convention that illustrates this approach, see The Convention on Transnational Organized Crime, G.A. Res. 55/25, A/RES/55/25 (2001).

144 O'Connell, supra note Erreur : source de la référence non trouvée, at 504 .

145 It should not be set up in the west so detached from the origination of modern extremism, but would be better suited to operate in the following states: Jordan, The United Arab Emirates, Egypt, Kuwait, India, South Africa, or Turkey. Due to the violent nature of many organizations against those who attempt to prevent it, the tribunal should be in an undisclosed location. 


\section{Conclusion}

At the UN Millennium Follow-up World Summit of $2005,{ }^{146}$ Heads of State unanimously affirmed that "each individual State has the responsibility to protect its populations from genocide, war crimes, ethnic cleansing and crimes against humanity." 147 They agreed that, when appropriate, the international community should assist states in exercising that responsibility by building their protection capacities before crises and conflict break out. ${ }^{148}$ However, when a state is "manifestly failing" to protect its population from the four specified crimes, then the international community must be prepared to take collective action, through the Security Council and in accordance with the Charter of the UN. ${ }^{149}$ When the United States declared a "war on terror" the global community was given a "false sense of security" which has continued through the Obama Administration. ${ }^{150}$

A legitimate nation-state attempting to dominate the world as Hitler's Germany sought to during the 1930s, is not the main genocidal threat to international security today now that nuclear weapons have advanced to a point that provides terrorist savages with the capabilities to commit mass murder with a single strike. ${ }^{151}$ The current definitions of terrorism are, therefore, not sufficient since the violence and beheadings are not perpetrated mainly to spread fear nor are they carried out to gain political momentum. Many modern terrorist

146 The 2005 World Summit, 14-16 September 2005, was a follow-up summit meeting to the United Nations' 2000 Millennium Summit

147 Mission Statement, UN: Office of the Special Adviser on the Prevention of Genocide, http://www.un.org/en/preventgenocide/ adviser/ (last visited Feb. 16, 2015).

148 See e.g. William J. Aceves, Liberalism and International Legal Scholarship: The Pinochet Case and the Move Toward a Universal System of Transnational Law Litigation, 41 Harv. Int'l L.J. 129 (discussing why there needs to be international consensus for prosecuting crimes of genocide and humanity).

149 Mission Statement, UN: Office of the Special Adviser on the Prevention of Genocide, supra note 210.

150 See Polish Foreign Minister admits US alliance has become harmful, Assoc. Press (June 22, 2014), http:/ /www.bing.com/r/1F/ CsAtd? $\mathrm{a}=1 \& \mathrm{~m}=\mathrm{EN}-\mathrm{US}$ (stating that recordings obtained from a private conversation displayed that Poland's strong alliance with the U.S. was worthless and "harmful because it creates a false sense of security" with a weakened leadership).

151 See Hoffman, supra note Erreur : source de la référence non trouvée, at 204-06 (showing that many extremists transnational organizations operate with genocidal intent and not an intent that seeks mainly to "incite fear for political purposes.") organizations possess the intent to exterminate, eliminate, and control. ${ }^{152}$ The world may see fear spread as a consequence of the growth of extremism, but these international criminal groups certainly intend not to merely incite fear (as the legal community currently sees "terrorist acts"), but rather, such organized violent groups intent to toss out the notions of civilization as we know it, and instill a form of global governance that oppresses and terrorizes those it subjects to its control and domination. ${ }^{153}$ Underestimating the threat of such genocidal campaigns, allowing them to remain unchallenged, enables them to achieve unprecedented power, unchallenged and unprosecuted in their quest to eliminate and exterminate mass numbers of innocent people. ${ }^{154}$

\section{Appendix A - The Proposed Redrafting of the Crime of Genocide to Incorporate Acts OF TERROR.}

I. The following shall be punishable as Genocide or Acts of Eliminationism:

a) intent to destroy, in whole or in part, a national, ethnical, racial or religious group, in the following manner: (1) Killing members of the group; (2) Causing serious bodily or mental harm to members of the group; (3) Deliberately inflicting on the group conditions of life calculated to bring about its physical destruction in whole or in part; (4) Imposing measures intended to prevent births within the group. ${ }^{155}$

b) Subjugation to violent and forced religious indoctrination

c) Purpose of global domination or mass extinction of any protected class of civilians including but not limited to: (a) Any national group; (b) Ethnic group; (c) Racial group; (d) Religious group; or (e) Gender group.

152 http://www.huffingtonpost.com/jim-wallis/5-things-toknow-about-is_b_6768668.html, Goldhagen, supra note Erreur : source de la référence non trouvée, at 498-99; Levitt, supra note Erreur: source de la référence non trouvée.

153 See Young, supra note Erreur : source de la référence non trouvée.

154 See e.g. Thomas L. Friedman, Say it like it is, supra note 197. 155 Rome Statute of the International Criminal Court, supra note Erreur : source de la référence non trouvée, art. 6. 
d) Recognizing that International Humanitarian laws protecting civilians must apply to transnational and unilateral violence carried out by non-state actors. Therefore, the global community agrees to amend the Geneva Conventions Protocol to include non-state extremism in its list of violators in order to subject them to the same Geneva Provisions.

e) Accepting the campaigns of self-determination. Do not Label Secession Movements As Terrorism.

II. The Foregoing acts shall be prosecuted as genocide and eliminationism campaigns in an individual capacity without regard to "state" status, non-state affiliation, political affiliation, or any other internationally recognized identifying mark.

- RehabilitationProgramsIn limited circumstances, member states and tribunal representatives shall agree to promote rehabilitative programs, where appropriate, to provide social reintegration of persons involved in the commission of terrorism if such individual was subject to duress, coercion, lack of age of consent or any other situation which the tribunal deems appropriate to allow for rehabilitation with the sole purpose of preventing the perpetration of terrorist acts in the future.

\section{APPENDiX B - Violations Of INTERNATIONAL Authorities by Terrorist Groups}

\begin{tabular}{|c|c|c|c|c|c|}
\hline Covenant & $\underline{\text { Hamas }}$ & $\underline{\text { ISIS }}$ & $\begin{array}{c}\underline{\mathrm{Al}-} \\
\text { Qaeda }\end{array}$ & $\frac{\text { Boko }}{\text { Haram }}$ & $\frac{\text { Hezbol- }}{\underline{\text { lah }}}$ \\
\hline $\begin{array}{l}\text { Genocide Conven- } \\
\text { tion arts. II (a) \& III } \\
\text { (b) \& (d), "genocide } \\
\text { means any of the } \\
\text { following acts com- } \\
\text { mitted with intent to } \\
\text { destroy, in whole or } \\
\text { in part, a national, } \\
\text { ethnical, racial or } \\
\text { religious group . . } \\
\text { [including] [k]illing } \\
\text { members of the } \\
\text { group; Conspiracy } \\
\text { to commit genocide; } \\
\text { Direct and public } \\
\text { incitement to com- } \\
\text { mit genocide." }\end{array}$ & X1 & $\mathbf{X}$ & $\mathbf{X} 2$ & X3 & X4 \\
\hline
\end{tabular}

(Human Rights Treaties) ICCPR art. 9(1) "[E]veryone has the right to freedom of thought, conscience and religion; this right includes freedom to change his religion or belief and freedom ... to manifest his religion or belief, in worship, teaching, practice, or observance." ICESCR art. 12

(1) \& (2) (d) States

Parties to the present Covenant recognize the right of everyone to the enjoyment of the highest attainable standard of physical and mental health. ... [and shall take] steps ... to achieve the full realization of this right [including] (d) The creation of conditions which would assure to all medical service and medical attention in the event of sickness.

Geneva Convention Common Article 3 (1) 1231(a)-(d) \& Additional Protocol II: “(1) Persons taking no active part in the hostilities. . . [shall] be treated humanely.

To this end, the following acts are and shall remain prohibited ... violence to life and person, in particular murder of all kinds, mutilation, cruel treatment and torture; taking of hostages; the passing of sentences and the carrying out of executions without previous judgment pronounced by a regularly constituted court, affording all the judicial guarantees which are recognized as indispensable by civilized peoples."

(Footnotes)

1 See Caroline Alexander, Hamas Releases End of Hope Video to 
Mark Israel Independence, Bloomberg News (May 6, 2014, 3:53 PM), http://www.bloomberg.com/news/2014-05-06/hamas-releasesend-of-hope-video-to-mark-israeli-independence.html (showing how Hamas released a video displaying its intent to commit mass genocide and displacement and take over Israeli territory).

2 See 9/11 Attacks, History Channel, http://www.history.com/ topics/9-11-attacks (last visited Feb. 16, 2015) (displaying the attacks committed by individuals acting in direct violation of the Genocide Convention and Geneva).

3 See Elias Meseret, Africa agrees to send 7,500 troops to fight Boko Haram, AP (Jan. 31, 2015 2:24 PM EST), http://bigstory. ap.org/article/8199f64eda1b475b873164943ec84e6d/africa-agreessend-7500-troops-fight-boko-haram.

4 See e.g. Deborah Passner, Hassan Nasrallah: In his own words, Frontpage Mag (July 26, 2006), http://archive.frontpagemag.com/ Printable.aspx?ArtId=3227.

5 See Simon Plosker, Foreign Journalists Acknowledge Hamas Human Shield Tactics, supra note Erreur : source de la référence non trouvée.

6 Facing fines or death, Christians flee Mosul, supra note Erreur : source de la référence non trouvée.
7 Bin Laden: al Qaeda, PBS.org, http://www.pbs.org/wgbh/ pages/frontline/shows/binladen/who/alqaeda.html (last visited Aug. 31, 2014).

8 Robert Windrem, While the World Watches ISIS, Boko Haram declares its own Caliphate ion Nigeria, NBC News (Sept. 15, 2014, 4:39 AM), http://www.nbcnews.com/storyline/missing-nigeriaschoolgirls/while-world-watches-isis-boko-haram-declares-its-owncaliphate-n202556

9 See e.g. B.B.C. Monitoring: Al-Manar, Hassan Nasrallah, supra note 116.

10 See Marc Schulman, Tel Aviv Diary: Public Executions in Gaza Reveal the True Nature of Hamas, Newsweek (Aug. 22, 2014, 12:46 PM), http://www.newsweek.com/tel-aviv-diary-public-executionsgaza-reveal-true-nature-hamas-266271.

11 See Boko Haram's treatment of Captured Nigerian girls detailed in new report, supra note Erreur : source de la référence non trouvée.

12 See Adam Goldman \& Ellen Nakashima, CIA and Mossad killed senior Hezbollah figure in car bombing, supra note Erreur : source de la référence non trouvée. 
Para publicar na Revista de Direito Internacional, acesse o endereço eletrônico www.rdi.uniceub.br ou www.brazilianjournal.org.

Observe as normas de publicação, para facilitar e agilizar o trabalho de edição. 